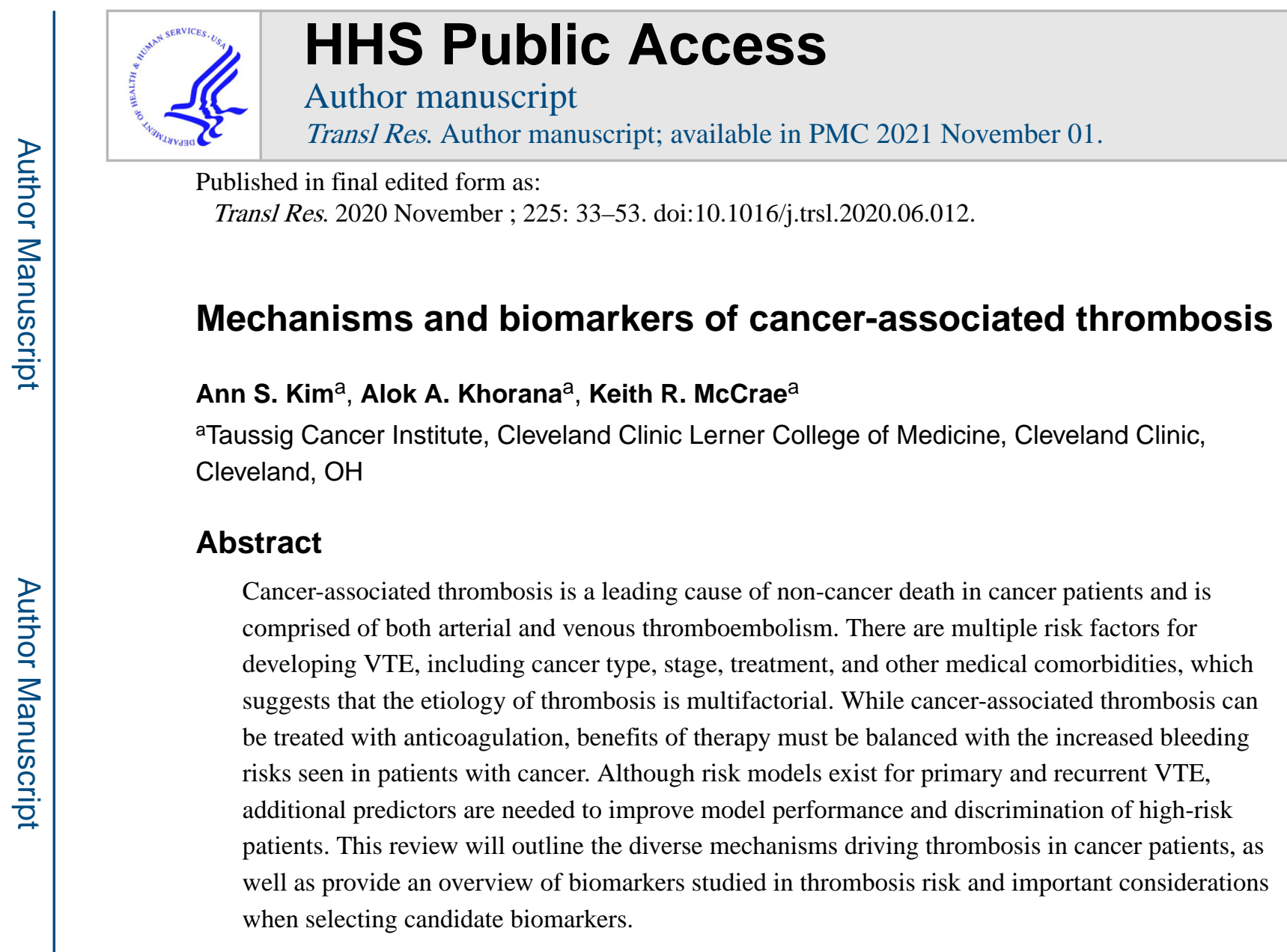

\title{
Introduction
}

Cancer-associated thrombosis (CAT), which includes both arterial and venous thromboembolism (VTE), is a significant complication and leading cause of non-cancer death in ambulatory cancer patients receiving systemic therapy. ${ }^{1}$ VTE has been more widely studied than arterial thromboembolism (ATE), with cancer patients having 4-7 times the risk of VTE compared to the general populace, generally concentrated in the first few months after cancer diagnosis. ${ }^{2,3}$ Interestingly, the timing of ATE risk appears to be more uniform, with a cumulative incidence of $1-5 \%$ at 6 -months after cancer diagnosis. ${ }^{4,5}$ More than half of deaths from pulmonary embolism are potentially preventable through appropriate prophylaxis, but risks of VTE must be balanced with increased bleeding risks in cancer patients while on anticoagulation. ${ }^{6,7}$ Known risk factors for VTE include cancer type, stage, treatment regimen, and comorbid disease with rates being highest in pancreatic, brain, and stomach cancer. ${ }^{8}$ This variety of risk factors likely reflects the multifactorial etiology of thrombosis in cancer. New advances in research have deepened the mechanistic knowledge driving CAT and have identified new targets for study.

Management of CAT is an evolving field, especially given the availability of new direct oral anticoagulants, and there is continued research on what are the best practices for improving CAT outcomes. Risk assessment models can guide clinical decision-making and are available for predicting primary VTE and recurrent VTE and include the Khorana, Vienna 
CATS, PROTECHT, CONKO, ONKOTEV, COMPASS-CAT, TiC-Onco, CATS nomogram, and Ottawa scores. ${ }^{9-17}$ However, these models have mixed performances and require further refinement to improve discrimination and identification of high-risk patients.

Biomarkers are measurable, biologic parameters that can be used to improve prediction, diagnostic, and prognostic models of disease. In CAT, they have been extensively studied for prediction of primary VTE risk (Table 1), with fewer studies on recurrent VTE (Table 2) and primary ATE (Table 3). No studies have assessed biomarker use in predicting risk of recurrent ATE.

While many potential biomarkers exist, selection of candidate biomarkers require consideration of scalability and practicality as their use transitions from research to clinical practice. Ideal biomarkers are noninvasive, low cost, simple to perform, accurate, and discriminative. ${ }^{18}$ During clinical practice, physicians may avoid ordering invasive or costly tests to reduce physical and fiscal patient burdens. Complex tests that rely heavily on skilled laboratory personnel or expensive technology can limit accuracy of biomarker measurement and reduce testing availability. Finally, biomarkers should be able to adequately separate patients with different risks. Biomarkers and their associated models must balance both simplicity, which encourages clinical use, with complexity and enhanced model performance to improve clinical outcomes. ${ }^{19}$

This review will cover key mechanisms underlying CAT and relevant biomarkers for risk assessment, along with associated challenges in biomarker assays (Table 4). Where appropriate, both mechanisms and biomarker roles will be described, but some topics will be limited to mechanistic or biomarker research. Detailed descriptions of CAT epidemiology, risk factors, and treatment have been previously described elsewhere and are beyond this scope of this review. ${ }^{8,20-24}$

\section{Extracellular Vesicles}

Mechanism-Extracellular vesicles (EVs) are defined by the International Society for Extracellular Vesicles (ISEV) as "the generic term for naturally released particles from the cell that are delimited by a lipid bilayer and cannot replicate". ${ }^{25}$ Historically, the literature has used the terms microvesicles or microparticles to generally refer to EVs that are $\leq 1000$ $\mathrm{nm}$ in size and derived from plasma membranes of cells. However, this classification is controversial and we will refer to these particles as EVs in this review, in accordance with ISEV guidelines. Cancer cells are capable of shedding EVs which can contain cell-specific surface proteins and cargo such as RNAs, DNAs, proteins, and lipid rafts. ${ }^{26-28}$

Intrinsic procoagulant activity of EVs stem from their negatively charged plasma membrane which serves as a catalytic surface for the vitamin K-dependent clotting factors: VII, IX, X, and prothrombin. This negative charge results from the asymmetric externalization of aminophospholipids, such as phosphatidylserine, from the inner plasma membrane leaflet during the formation of EVs by calcium-dependent scramblases, such as TMEM16F. ${ }^{29-31}$ Phosphatidylserine on EVs binds clotting factors through their positively charged $\gamma$ carboxyglutamic acid domains and increases catalytic efficiency of phospholipid-dependent 
coagulation reactions such as the tenase and prothrombinase complexes by 3 orders of magnitude. ${ }^{32}$

EVs also contain differential procoagulant activity depending on their mechanism of formation and cargo contents. Prothrombotic surface proteins and cargo include tissue factor (TF), inflammatory molecules, and podoplanin. A simplified model of key mechanisms occurring in blood are presented in Figure 1.

Biomarker Use in Primary VTE Risk-Studies on VTE risk with total EV quantities are limited. In a prospective study of newly diagnosed and progressive disease cancer patients, procoagulant activity of EVs due to the exposure of negatively charged phospholipids, as quantified by a prothrombinase assay, was not significantly associated with VTE risk (HR [hazard ratio] 0.95, 95\% CI [confidence interval] 0.55-1.64). ${ }^{33}$

Testing of EVs falls broadly into phenotypic or functional assays and include flow cytometry, electron microscopy, confocal microscopy, and atomic force microscopy in addition to function-specific assays. Phenotypic assays allow for quantification and assessment of morphology and cellular origin of EVs. Flow cytometry is the most common assay for EV quantification and assessment of cellular origin. Electron microcopy can study membrane morphology and composition, while confocal microscopy can evaluate cellular origin. Atomic force microscopy measures interaction forces between a cantilever tip and the test sample, allowing for three-dimensional topography construction as well as quantification. ${ }^{34}$ Functional assays commonly require extraction of EVs by capture techniques or ultracentrifugation prior to study.

While research on EVs as biomarkers has rapidly grown, reproducible and reliable testing of EVs has been hampered by both pre-analytical and analytical obstacles. Differences in preanalytical steps, such as blood collection, sample processing, and handling and storage can severely impact the testing results. For example, traumatic blood collection can activate platelets and falsely increase EV quantity, while different centrifugation speeds will impact extraction efficiency of EVs. ${ }^{34,35}$

Analytical challenges are intrinsic to the assay itself, such as older flow cytometers having limited capability to detect smaller EVs. ${ }^{35}$ These obstacles, combined with the sheer diversity of assay options makes EV testing for biomarkers candidacy difficult as they invoke problems of assay accuracy and limited comparability of results depending on assay selection. Given the complicated landscape of EV experimentation, ISEV has published guidelines for studying EVs with the most recent update in 2018 and protocols for biofluid collection and EV isolation/enrichment are available through the Extracellular RNA Communication Consortium (ERCC). ${ }^{25,36}$

\section{Tissue Factor/Tissue Factor-Positive Extracellular Vesicles}

Mechanism-TF is a procoagulant protein that initiates the extrinsic pathway of the coagulation cascade, leading to thrombin and fibrin clot formation. TF is expressed on perivascular cells such as fibroblasts and vascular smooth muscle cells and binds factor VII to stabilize its catalytic domain for downstream activation of factors IX and X. TF 
expression can also be induced in monocytes and endothelial cells upon activation with ligands such as lipopolysaccharide and released in TF extracellular vesicles $\left(\mathrm{TF}^{+} \mathrm{EVs}\right)$, although small subsets of resting monocytes have also been shown to express TF. ${ }^{37-41}$ In contrast, malignant tissues can constitutively express $\mathrm{TF}$ and release $\mathrm{TF}^{+}$EVs. ${ }^{42-48}$

Clinical studies of cancer patient plasma have shown elevated $\mathrm{TF}$ and $\mathrm{TF}^{+} \mathrm{EV}$ expression and activity, including in breast, colorectal, prostate, gastric, brain, and pancreatic cancers. ${ }^{49-56}$ However, the source of $\mathrm{TF}^{+} \mathrm{EVs}$ in cancer patients is unclear and likely results from multiple etiologies, including host and malignant cells. ${ }^{51,52,57}$ Studies in nonmalignant settings have shown generation of $\mathrm{TF}^{+} \mathrm{EV}$ s from endothelial cells, monocytes, and macrophages ${ }^{58}$ Platelet TF expression and $\mathrm{TF}^{+} \mathrm{EV}$ generation is controversial with discrepant results of expression and function being reported. ${ }^{59-66}$ Some of these conflicting results may be attributed to the use of non-specific anti-TF antibodies and Xa functional assays. ${ }^{67}$ This issue is further complicated by monocyte-derived TF which can be transferred to platelets via EVs and can represent a contaminating source of TF if not adequately removed from the samples of interest. ${ }^{67-71}$ Together, these findings suggest that while platelets may not have intrinsic expression of TF, they can acquire TF through external sources. Notably, although TF may be present on platelet-derived EVs, the thrombogenicity of these EVs appears to be driven primarily by exposed phosphatidylserine, rather than $\mathrm{TF}^{72}$ In contrast, thrombin formation from EVs derived from lipopolysaccharide-stimulated monocytes was effectively inhibited by anti-TF antibodies, suggesting that TF on monocytederived EVs plays a greater thrombogenic role than on platelet-derived EVs. Similar to platelets, granulocytes have been shown to take up external TF from monocytes. ${ }^{73,74}$

Despite elevated expression and activity in malignancy, consistent association of TF or $\mathrm{TF}^{+}$ EVs with VTE have only clearly been shown in pancreatic cancer. ${ }^{75,76}$ While studies of thrombotic risk in cancer patients with $\mathrm{TF}$ or $\mathrm{TF}^{+} \mathrm{EV}$ s have primarily focused on VTE, a recent study has shown that $\mathrm{TF}^{+} \mathrm{EVs}$ were elevated in patients with cancer-related stroke compared to those with cancer-unrelated stroke. ${ }^{77}$ However, $\mathrm{TF}^{+}$EVs did not mediate an association between cancer-cell derived EVs and D-dimer levels by statistical path analysis; effects of $\mathrm{TF}^{+} \mathrm{EVs}$ on cancer-related stroke were not modeled.

In pancreatic cancer mouse models, platelet-dependent and independent pathways have been proposed for $\mathrm{TF}^{+} \mathrm{EV}$ induced thrombosis. In platelet-dependent thrombosis, $\mathrm{TF}^{+} \mathrm{EVs}$ localize at thrombus sites by binding markers such as P-selectin to activate and aggregate platelets via a TF-dependent pathway. ${ }^{45,47}$ Recently, a platelet- and leukocyte-independent mechanism was shown that requires host TF to initiate thrombus formation for propagation by phosphatidylethanolamine-dependent $\mathrm{TF}^{+} \mathrm{EVs}^{78}$

Biomarker Use in Primary VTE Risk-In prospective studies of mixed cancer and multiple myeloma patients, $\mathrm{TF}^{+} \mathrm{EV}$ activity as measured by a TF-dependent factor $\mathrm{Xa}$ generation assay did not significantly correlate with VTE risk. ${ }^{55,79}$ Similarly, a prospective study of mixed cancer patients using a fibrin generation assay for $\mathrm{TF}^{+} \mathrm{EV}$ activity showed no association with increased VTE risk (sHR [subdistribution hazard ratio] 1.94, 95\% CI 0.99-3.80). ${ }^{80}$ However, a retrospective study showed that pancreaticobiliary patients had 4.78 times the risk of developing VTE (95\% CI 1.64-13.98) with $\mathrm{TF}^{+} \mathrm{EV}$ activity $\geq 2.5$ 
$\mathrm{pg} / \mathrm{ml}$, as measured by TF-dependent factor Xa generation. ${ }^{56}$ In a prospective study of pancreatic cancer patients, $\mathrm{TF}^{+} \mathrm{EV}$ activity $\geq 2.37 \mathrm{pg} / \mathrm{ml}$ by TF-dependent factor Xa generation increased VTE risk by 10.5 -fold, although precision of the estimated risk was low (95\% CI 1.5-72.4). ${ }^{81}$ A meta-analysis of cancer patients showed an increased $76 \%$ risk of VTE with elevated $\mathrm{TF}^{+}$EV quantity or function (95\% CI 1.21-2.56). ${ }^{82}$ Subgroup analyses revealed that the increased risk was driven by elevated $\mathrm{TF}^{+} \mathrm{EV}$ levels on flow cytometry assays (OR [odds ratio] $2.97,95 \%$ CI 1.81-4.86) rather than activity assays (OR $1.25,95 \%$ CI $0.95-1.65){ }^{82}$

$\mathrm{TF}^{+} \mathrm{EV}$ assays are often based on factor Xa generation using a chromogenic substrate after incubation with factors VII and X in the presence of anti-TF antibodies. These assays can incorporate exogenous addition of negatively charged phospholipids, which may increase total factor Xa generation in a TF-independent manner. ${ }^{83}$ Another $\mathrm{TF}^{+} \mathrm{EV}$ functional assay is the fibrin generation test which measures fibrin formation using optical densitometry in the presence of anti-factor VIIa antibodies. ${ }^{84}$

When studying specific sources of $\mathrm{TF}^{+} \mathrm{EV}$, a serious pre-analytical challenge includes monocytes which can be a major source of contaminating TF and care should be taken to purify samples, such as by using microbeads bound to anti-CD14 antibodies. ${ }^{67,71}$ In regards to analytical challenges, flow cytometry assays are not recommended as they suffer from poor specificity of anti-TF antibodies, which bind non-specifically at high concentrations and may cross-react with phosphatidylserine on cell membranes. ${ }^{67,85,86}$ Enzyme-linked immunosorbent assays (ELISA) suffer from similar poor antibody specificity and selectivity.

${ }^{67}$ Functional assays of $\mathrm{TF}^{+} \mathrm{EV}$ activity have variable specificity depending on the methods used, as TF-independent mechanisms can also generate factor Xa. One method to limit TFindependent Xa generation in these assays is to add prothrombin, FVa, and phospholipids and reduce incubation time to 3-4 minutes, rather than the standard minimum incubation time of 60 minutes. ${ }^{67,87}$ An alternative method avoids adding exogenous phospholipids, but is time consuming with high interassay variability and therefore not appropriate for clinical use. ${ }^{83,88}$

\section{Neutrophils and Neutrophil Extracellular Traps}

\section{Mechanism}

Activated neutrophils can form neutrophil extracellular traps (NETs), which are extracellular fibers containing histones, DNA, and proteins derived from neutrophilic granules. ${ }^{89}$ While they were originally discovered in the role of host defense, neutrophils and NET formation, also known as NETosis, have since been proposed to be a mediator of CAT. During thrombus formation, neutrophils are the first leukocyte to arrive at the site of vessel injury, only secondary to TF. ${ }^{90,91}$ Stimulation of neutrophils by multiple factors including activated endothelial cells, activated platelets, interleukin-8 (IL-8), tumor necrosis factor-a (TNF-a), and granulocyte-colony stimulating factor (G-CSF) can induce NETosis, which serves as a scaffold for platelets, red blood cells, and other procoagulants. ${ }^{92-94}$ During NETosis, neutrophils swell and lose their nuclear membrane integrity leading to mixing of chromatin, histones, and granule-derived proteins. ${ }^{95}$ Peptidylarginine deiminase 4 is a required nuclear 
enzyme for NETosis that citrullinates arginine residues of histones $\mathrm{H} 3$ and $\mathrm{H} 4$ and causes dissociation of chromatin from histones due to the loss of electrostatic force. ${ }^{96}$

Histones present in NETs activate platelets through Toll-like receptors 2 and 4, leading to thrombin generation. ${ }^{97}$ Furthermore, histones induce endothelial cells to release von Willebrand factor (vWF) which binds glycoprotein Ib (GPIb) on platelets, leading to vessel wall adhesion and clot initiation. ${ }^{98,99}$ Histone-independent activation of platelets can also occur via direct binding of platelets to cell free DNA (cfDNA), as well as cathepsin G activity. ${ }^{100}$ Cathepsin $\mathrm{G}$ and neutrophil elastase are present on NETs and inhibit TF pathway inhibitor to enhance TF and factor XII-dependent fibrin and thrombus formation. ${ }^{101,102}$ Neutrophils have also been shown to both release TF and EVs. ${ }^{103-106}$ Neutrophil- and tumor-derived EVs scaffold to NETs through phosphatidylserine-histone interactions and contribute to thrombosis. ${ }^{106-108}$

In mouse studies of cancer, tumor-bearing mice were associated with increased neutrophil counts, G-CSF, cfDNA, citrullinated histone H3 (H3Cit), and NET formation. ${ }^{94,109}$ Thrombi from a mouse model of human pancreatic cancer also contained elevated levels of $\mathrm{H} 3 \mathrm{Cit}$, cfDNA, and the neutrophil marker Ly6G, and were reduced in size with neutrophil depletion and DNase treatment. ${ }^{109}$ Tumor-derived EVs also increased NET formation from mouse neutrophils treated with G-CSF and injection of these EVs increased venous thrombus formation in vivo. ${ }^{108}$

NET markers such as nucleosomes, cfDNA, and H3Cit are also elevated in cancer patients. 110-112 In a case-control study of patients with ischemic stroke, elevated post-stroke levels of $\mathrm{H} 3 \mathrm{Cit}$ were associated with positive cancer status, elevated thrombin-antithrombin complexes, and soluble P-selectin levels. ${ }^{111}$

Biomarker Use in Primary VTE Risk-Research on NET-related biomarkers in CAT has just begun with a prospective study of cancer patients showing that each $100 \mathrm{ng} / \mathrm{ml}$ increase in plasma H3Cit was associated with an $11 \%$ increase in VTE (95\% CI 1.03-1.20). ${ }^{112}$ Upon subgroup analysis by cancer type, only pancreatic and lung cancers showed a significantly increased risk of VTE with elevated H3Cit levels. However, these results should be cautiously interpreted as the study was underpowered for subgroup analysis. Elevated nucleosome and cfDNA levels were not significantly correlated with VTE. Studies on neutrophil-to-lymphocyte ratios (NLR) have also been explored in cancer patients but have failed to show significance. ${ }^{113-115}$ Plasma H3Cit can be measured by ELISA, but clinical access to this assay is not yet widely available. ${ }^{116}$

\section{Inflammatory Molecules}

Mechanism-Cancer cells synthesize and secrete a variety of inflammatory molecules that have diverse procoagulant capabilities, including TNF-a, IL-1 $\beta$, IL-6, IL-8, and vascular endothelial growth factor (VEGF). TNF- $\alpha$, IL-1 $\beta$, and IL- 6 can induce TF expression and activity from endothelial cells. ${ }^{117,118}$ TNF-a has also been shown to increase EV release from cancer cells, with elevated TF activity seen on EVs derived from lung, pancreatic, and colon cancer. ${ }^{119}$ TNF- $\alpha$ and IL-1 $\beta$ can also upregulate plasminogen activator inhibitor-1 (PAI-1), although fibrinolysis was not completely abolished in cancer patients after TNF-a 
infusion. ${ }^{120,121} \mathrm{IL}-1 \beta$ has been shown to be synthesized by activated platelets from premessenger RNA stored in polysomes which are spliced to messenger RNA (mRNA) upon activation and can be released in platelet EVs to interact with other inflammatory cells. ${ }^{122}$ Platelets can also express IL-1 receptor and respond to IL-1 $\beta$ in an autocrine loop to amplify platelet activation. ${ }^{123}$ IL-8 expression can be induced by fibrin and has been shown to induce granulocyte chemotaxis and NET formation. ${ }^{124-126}$ Finally, VEGF can upregulate TF expression in endothelial cells via the transcription factor early growth response $1 .{ }^{127}$ TF has also been shown to induce VEGF expression in tumor cells and may represent a potential positive procoagulant feedback loop. ${ }^{128}$

Biomarker Use in Primary VTE Risk-Data on the use of inflammatory molecules for VTE risk have been mixed. A retrospective study demonstrated ovarian cancer patients with plasma IL-6 levels $\geq 20 \mathrm{pg} / \mathrm{ml}$ had 8.9 times the risk of developing VTE, although precision of the increased VTE risk is low (95\% CI 1.04-76.0). ${ }^{129}$ In contrast, a prospective study on diffuse large B cell lymphoma patients showed no association VTE risk with IL-6, IL-10, or TNF-a. ${ }^{130}$ Similarly, a prospective study of solid tumor patients showed no association of IL-1 $\beta$, IL-3, IL-4, IL-6, IL-8, IL-10, IL-11, or chemokine ligand 3 (CCL3) with VTE. ${ }^{131}$ In glioma patients, for each two-fold increase in $\mathrm{pg} / \mathrm{ml}$ of CCL3, VTE risk was reduced approximately $60-80 \%$, depending on other variables in the Cox regression model. ${ }^{132}$ In the same study, IL-1 $\beta$, IL-4, IL-6, IL-8, IL-10, IL-11, TNF- $a$, and VEGF were not found to be significantly associated with VTE. ${ }^{132}$ However in a study of metastatic colorectal cancer patients, low pre-chemotherapy serum TNF-a levels $(<6.6 \mathrm{pg} / \mathrm{ml})$ decreased VTE risk by $83 \%$ (95\% CI 0.04-0.75), but the estimated effect is imprecise due to the wide CI. ${ }^{133}$ Another study showed that for every $10 \mathrm{pg} / \mathrm{ml}$ increase in soluble VEGF, VTE risked increased by $4 \%$ (95\% CI 1.00-1.09) in cancer patients. ${ }^{134}$

Inflammatory markers are common candidates for biomarkers and can be assayed with ELISA, enzyme-linked immune spot assays (ELISPOT), polymerase chain reaction (PCR), and multiplexed bead- or protein-based arrays. ${ }^{135}$ These markers are advantageous as quantitative assays are readily available in clinical practice, and many markers can be assayed at once through multiplexing. However, cytokines have short half-lives, diurnal variation, and are prone to degradation with multiple freeze-thaw cycles. Furthermore, sample preparation, such as collecting serum or plasma and anticoagulation choice can affect cytokine synthesis and release after blood collection. ${ }^{136}$ When considering these markers for risk models in clinical practice, blood collection procedures should be developed in accordance with the assays used. EDTA-treated tubes provide consistent results for most cytokine immunoassays, although citrate can also be considered. If using bioassays, blood should be collected in tubes for serum preparation or low-level preservative free-heparin tubes for plasma preparation. Blood should be processed immediately within two hours after collection and samples divided into small aliquots to minimize need for repeated freezing and thawing. Freeze-thaw cycles should be limited to no more than 3 cycles and stored samples should be used within approximately 4 years, depending on the specific cytokines of interest. ${ }^{136,137}$ 


\section{Podoplanin and Isocitrate Dehydrogenase 1}

Mechanism-Podoplanin is a transmembrane glycoprotein that is normally present in a variety of normal tissue, including lymphatic endothelial cells, kidney podocytes, type 1 alveolar lung cells, and lymph node fibroblastic reticular cells, but not vascular endothelial cells. ${ }^{138,139}$ Expression is also seen in cancer cells such as squamous cell carcinomas, germinal tumors, brain tumors, mesotheliomas and acute promyelocytic leukemia. ${ }^{138-140}$ Podoplanin binds to the C-type lectin-like receptor 2 (CLEC-2) on platelets to induce platelet activation and aggregation. ${ }^{141,142}$

Elevated expression of podoplanin has been observed in primary brain cancer tissue as well as in podoplanin-containing EVs in the blood of pancreatic cancer patients. ${ }^{143,144}$ A mouse melanoma (B16F10) model has shown podoplanin-dependent thrombus formation through CLEC-2-podoplanin interaction. ${ }^{145}$ While podoplanin can arise from cancer cells, it can also be abnormally induced by thromboinflammation in host vascular cells. In a mouse model of inferior vena cava stenosis, podoplanin was expressed in the inferior vena cava vessel wall after 48 hours of stenosis. ${ }^{146}$

Isocitrate dehydrogenase 1 (IDH1) is commonly mutated in gliomas and the mutant form has been associated with decreased VTE in glioma patients compared to the IDH1 wildtype. ${ }^{147}$ Mutated IDH1 can produce D-2-hydroxyglutarate to reduce platelet aggregation and clotting activity in vitro. ${ }^{147}$ IDH1 mutants are also associated with increased $F 3$ promoter hypermethylation and decreased $F 3$ mRNA transcripts, leading to decreased TF expression in vitro, which could be reversed with a demethylating agent. ${ }^{147,148}$ Notably, IDH1 mutations are associated with hypermethylation in human gliomas, but not in acute myeloid leukemia, cholangiocarcinoma, or melanoma, suggesting that the protective effects of IDH1 mutation are specific to the brain cancer setting. ${ }^{149}$

Biomarker Use in Primary VTE Risk-Studies using brain cancer patients from the Vienna CATS cohort have shown increased risk of VTE with $>70 \%$ podoplanin expression in tumor tissue (HR 5.71, 95\% CI 1.52-21.36) and a score 23 based on a combined scoring system of podoplanin tissue expression and IDH1 mutant status (3 points: HR 8.4, 95\% CI 1.04-67.58; 4 points: HR 13.28, 95\% CI 1.65-106.97). ${ }^{143,150}$ However, the reported CIs are wide and demonstrate low precision of estimated VTE risk. Furthermore, because the studies do not report the timing of VTE events relative to acquisition of tumor sample for podoplanin expression and IDH1 genotyping, causative conclusions about the effect of podoplanin and IDH1 on VTE risk cannot be made. In a separate study of newly diagnosed glioma patients, podoplanin tissue positivity ( $230 \%$ expression) and IDH1 mutant status were significantly correlated with subsequent VTE risk with low precision of estimated risk (OR 3.423, 95\% CI 1.083-10.814; OR 0.101, 95\% CI 0.010-0.975, respectively). ${ }^{151}$

Podoplanin and IDH1 tissue expression are assessed histologically after immunostaining of tumor tissue. While these assays can be completed in the clinical setting, the invasive nature of tissue collection, especially in the setting of brain cancer, can delay and limit use of risk models. 


\section{Extracellular microRNAs}

Mechanism-MicroRNAs (miRNAs) are small noncoding RNAs that are about 20-22 nucleotides in length and function as inhibitors of gene expression. miRNAs bind to complementary sequences on target mRNAs at 3' untranslated regions and form miRNAinduced silencing complexes with Argonaute proteins leading to mRNA degradation. ${ }^{152}$ miRNAs can be released into plasma bound to Argonaute proteins or in vesicles, but the relative proportions of protein- and vesicle-bound miRNAs are unclear. ${ }^{153}$ Interestingly, miRNAs have also been found in anucleate platelets; these can be shed in EVs and transferred to other cells for gene regulation, suggesting a potential role for intercellular signaling. ${ }^{154-156}$

Dysregulation of miRNAs are associated with increased procoagulant phenotypes. In patients with systemic lupus erythematosus and antiphospholipid syndrome, miR19-b and miR-20a, which inhibit TF, were significantly decreased compared to healthy controls and may contribute to their hypercoagulable states. ${ }^{157}$ Case-control studies of acute, noncancerous deep vein thrombosis and recurrent VTE patients also showed distinct miRNA profiles in cases compared to controls. ${ }^{158,159}$ Similarly, in a case-control study of colorectal cancer patients, 9 miRNAs were differentially expressed in patients who developed VTE compared to controls. ${ }^{160}$

Biomarker Use in Primary VTE Risk-Studies assessing miRNA biomarkers for cancer VTE risk are limited. Recently, a study on newly diagnosed pancreatic and cholangiocarcinoma patients assessed the predictive capabilities of miRNAs for primary VTE. Study subjects were split into screening $(n=10)$ and confirmatory groups $(n=32)$ and 7 miRNAs (miR-486-5p, miR-106b-5p, let-7i-5p, let-7g-5p, miR-144-3p, miR-19a-3p and miR-103a-3p) were identified for inclusion in a predictive model. Model testing in the confirmatory group demonstrated a receiver operating characteristic (ROC) curve area under the curve of 0.95 (95\% CI 0.87-1). ${ }^{161}$ However, the number of events included in this study is small for the number of predictors included in regression modeling and patients from the screening cohort were also included in the confirmatory group, leading to a highly overfit model and results. Nevertheless, miRNAs are a growing field of study in CAT and further studies are needed.

New advances in miRNA assays are appearing rapidly, but quantification is most commonly done through quantitative reverse transcription polymerase chain reaction (qRT-PCR), hybridization assays such as microarrays, and next-generation sequencing. Hybridization platforms such as microarrays are often low-cost and have fast turnaround times with highthroughput but have the lowest specificity. qRT-PCR performs similarly with improved specificity. Next-generation sequencing is the most costly, but is the only assay that can identify novel miRNAs, and with continued technological advances, cost has dropped dramatically over time. ${ }^{162}$

While miRNAs are exciting candidate biomarkers, there are considerable challenges for research and clinical use, similar to EVs. Though miRNAs are quite stable both at room temperature and upon multiple freeze-thaw cycles, study of miRNAs remain challenging due to their multiple transport mechanisms (RNA-binding proteins, EVs), technical difficulties in 
isolation and data analysis, and lack of widely used standards. ${ }^{163}$ Prior studies have shown there are significant biases in RNA isolation and library preparation kits that can impact results. ${ }^{164,165}$ Furthermore, data analysis is hampered by the lack of endogenous normalization controls which has generated controversy on the most appropriate normalization methods. ${ }^{166}$ The ERCC was formed to combat these challenges and create guidelines for standardization of testing. ${ }^{36,167}$

\section{Polyphosphate and the Contact Pathway}

Mechanism-Polyphosphates (polyPs) are linear polymers of anionic phosphate units that promote length-dependent mechanisms of thrombosis. On microbes, polyPs are found in a long chain form ranging from tens to thousands of units which activates the contact pathway through generation of factor XIIa and kallikrein. ${ }^{168-170}$ Short chain forms of polyP are released by platelets from dense granules which function to accelerate factor XI and V activation for enhanced thrombin generation. ${ }^{171-175}$ Short chain polyP also inhibits TF pathway inhibitor and remodels fibrin clots to increase resistance to fibrinolysis. 169,174,176,177 Activated platelets can also express membrane-associated polyPs as spherical nanoparticles which potently activate factor XII and the contact pathway. ${ }^{178}$

The contact pathway, or contact activation system, is a proteolytic pathway including factors $\mathrm{XII}, \mathrm{XI}$, prekallikrein (PK), and high molecular weight kininogen $(\mathrm{HK})$ that is activated upon contact of factor XII with a negatively charged surface, such as polyP or cfDNA, leading to cleavage of PK into kallikrein, which generates bradykinin from HK. ${ }^{179}$ Factor XII-independent contact activation can also occur via HK-PK complexes on endothelial cells leading to PK activation and cleavage. ${ }^{179}$ The principal inhibitor of the pathway is $\mathrm{C} 1$ esterase inhibitor which inhibits factor XIIa and kallikrein. ${ }^{180}$

Human studies investigating the role of polyP in cancer and CAT have not yet been reported. However, prostasomes or prostate-cancer derived EVs express long chain polyP that potently induces pulmonary embolism in mouse models through factor XII-dependent mechanisms, suggesting a potential role in prostate CAT. ${ }^{181}$

Current studies of contact pathway function in cancer patients are limited, but suggest that activation of the contact pathway leads to consumption and decrease of factor XII in gastrointestinal, colorectal, and lung cancer patients. ${ }^{182-184}$ In prostate cancer, patientderived exosomes showed significantly more thrombin generation potential and factor XIIa activity compared to controls. ${ }^{181}$

\section{Plasminogen Activator Inhibitor-1}

Mechanism-PAI-1 is a serine protease that inhibits tissue plasminogen activator and urokinase, which are activators of plasminogen and fibrinolysis. Elevated levels of PAI-1 have been found in glioma, non-small cell lung, multiple myeloma, and pancreatic cancer patients. ${ }^{185-188}$ However, studies of PAI-1 in CAT are limited and even in nonmalignant settings, there has been limited evidence to support PAI-1-associated VTE. ${ }^{189}$ An in vitro study of human umbilical vein endothelial cells treated with PAI-1 lead to increased EV release, which were associated with increased anionic phospholipid expression and thrombin 
generation. ${ }^{190}$ Interestingly, a mouse lung cancer model showed increased expression of PAI-1 in tumor tissue and plasma after treatment with bevacizumab, an antiangiogenic VEGF antibody that is associated with increased VTE in cancer patients, suggesting that PAI-1 may play a more significant procoagulant role in antiangiogenic therapy-based VTE. 191,192

\section{Platelet Activators}

Mechanism-Platelets are key actors in thrombus formation and can interact with cancer cells for enhanced activation and aggregation. Resting platelets adhere to and are activated at sites of endothelial damage upon binding of exposed vWF through GPIb, leading to rise of intracellular calcium which drives shape change and degranulation of adenosine diphosphate (ADP), fibrinogen, GPIb, and glycoprotein IIb/IIIa (GPIIb/IIIa). Further activation is driven by newly released ADP, thromboxane $\mathrm{A} 2\left(\mathrm{TxA}_{2}\right)$, and CD40 ligand (CD40L). ADP is stored in dense granules and upon release binds receptors $\mathrm{P} 2 \mathrm{Y} 1$ and $\mathrm{P} 2 \mathrm{Y} 12$ on platelets for activation. TxA $\mathrm{A}_{2}$ is synthesized by thromboxane synthase after platelet activation and diffuses readily across the plasma membrane for binding of $\mathrm{TxA}_{2}$ receptor on platelets. CD40 is expressed on activated platelets and binds soluble CD40L which is released after platelet activation. Thrombin, a serine protease, can also activate platelets by cleaving the extracellular domains of protease-activated receptors 1 and 4 (PAR1/PAR4) on platelet membranes. After activation, platelets aggregate through crosslinking of fibrinogen and vWF with GPIIb/IIIa, forming the hemostatic plug. ${ }^{193,194}$

Cancer cells are capable of secreting these platelet activating factors and in vitro studies have shown release of tumor-derived ADP, TxA 2 , and CD40L, leading to tumor cell-induced platelet aggregation. ${ }^{195-198}$ Thromboxane synthase overexpression with increased $\mathrm{TxA}_{2}$ metabolites have also been demonstrated in cancer cell lines and human tissue. ${ }^{199-203}$ Additionally, large multimers of vWF have been found in the plasma of patients with disseminated cancer and vWF expression has been reported in both patient-derived glioblastoma and glioma and osteosarcoma cell lines. ${ }^{204,205}$ Platelet-tumor cell interactions using these activating factors have well-established roles in metastasis, where platelets coat tumor cells to provide a protective covering against host immune cells and allow tumor cell adhesion to endothelium for extravasation at distal tissue sites. ${ }^{206-208}$ These same interactions may also play a role in CAT.

\section{Blood Count}

Biomarker Use in Primary VTE Risk-Blood counts such as leukocyte and platelet count have been widely studied as biomarkers of primary VTE and are used broadly across many risk models. In prospective studies of cancer patients, both elevated leukocyte $(>11 \times$ $10^{9} / 1$ ) and platelet ( $350 \times 109 / 1$ ) counts increased risk of initial VTE. ${ }^{9,14,209}$ This elevated risk remained when assessing leukocyte counts per 2-fold increase and elevated platelet counts as $\geq 443 \times 109 / 1 .{ }^{210}$ Leukocyte and platelet counts feature in the Khorana, Vienna CATS, PROTECHT, CONKO, and COMPASS-CAT scores. ${ }^{9-12,14}$ Leukocyte and platelet counts are assayed through the complete blood count (CBC) and are ubiquitously available in clinical practice. Furthermore, $\mathrm{CBC}$ tests are routinely acquired during typical management of patients, which reduces testing burden of patients during risk modeling. 


\section{D-dimer}

Biomarker Use in Primary VTE Risk-D-dimer is a degradation product of plasmininduced fibrinolysis and is one of the most common biomarkers studied for primary VTE development in cancer patients. Prospective studies of newly diagnosed cancer patients have shown that elevated pre-treatment levels of D-dimer increase the risk of primary VTE in colorectal, gynecologic, and mixed cancer populations. ${ }^{211-214}$ Another prospective study on newly diagnosed cancer patients and those with disease progression also found increased levels of D-dimer with elevated risk of primary VTE (HR 1.8, 95\% CI 1.0-3.2). ${ }^{215}$ In a retrospective study of lung cancer patients who were categorized as intermediate risk by the Khorana score, elevated prechemotherapy D-dimer levels were associated with increased risk for VTE (HR 11.0, 95\% CI 2.62-46.2), suggesting that D-dimer levels may help discriminate between intermediate Khorana score patients. ${ }^{216}$ However, due to the wide CI, the precision of estimated VTE risk is low. Borderline associations of D-dimer levels with VTE risk have also been demonstrated. ${ }^{81,112} \mathrm{D}$-dimer has been incorporated into the Vienna CATS and CATS nomogram risk models. ${ }^{10,16}$

Assays for D-dimer quantification include ELISA, enzyme-linked immunofluorescence assays (ELFA), latex-based assays, and whole-blood assays. While ELISA-based values represent the reference assay for D-dimer, ELFA and latex-based assays provide faster turnaround times and are fully automated. Whole-blood is often used for point-of-care testing and suffers from low sensitivity. 217

A major obstacle with D-dimer quantification is the lack of transparency on unit measurement in laboratory reports, which can be expressed as purified D-dimer units (DDUs) or fibrinogen equivalent units (FEUs), with 1 FEU being equivalent to approximately 2 DDUs. ${ }^{217,218}$ This discrepancy makes development of standard D-dimer cut-offs difficult, as chosen cut-off limits in different studies may not be comparable. In clinical practice, physicians may input incorrect units of D-dimer into risk models and reduce validity of their results. We recommend that D-dimer biomarker research clearly state which assay and D-dimer unit type is used and that risk calculators specify D-dimer unit type when allowing users to input data. Furthermore, D-dimer levels increase with age, contributing to the difficulty in developing standard reference levels. ${ }^{219}$ Finally, levels of Ddimer may be elevated in a variety of inflammatory settings, not directly linked to activation of the coagulation system. ${ }^{220}$

\section{P-selectin}

Biomarker Use in Primary VTE Risk-P-selectin is a cell adhesion molecule found on activated endothelial cells and platelets and can be released into plasma, including on EVs. Multiple prospective studies derived from the Vienna CATS cohort have shown that increased soluble P-selectin levels are correlated with VTE risk, with one study estimating that a soluble P-selectin level $\geq 53.1 \mathrm{ng} / \mathrm{ml}$ increased the risk of VTE by 2.6 -fold (95\% CI 1.4-4.9). ${ }^{132,134,214,221}$ However, in another study based on the Vienna CATS cohort, soluble P-selectin levels were not significantly correlated with increased risk. ${ }^{112}$ Soluble P-selectin is measured by ELISA, and while assays are available for research purposes, clinical assays are not widely available. Although the Vienna CATS risk model may improve VTE 
prediction, the lack of access to soluble P-selectin assays limit its proposed clinical function. 10

\section{Biomarkers in Recurrent VTE Risk}

The Ottawa score is a risk model for recurrent VTE and includes predictors for sex, primary tumor site (lung or breast), stage, and prior VTE. ${ }^{17}$ However, subsequent validation studies have shown mixed results on its discriminative capability, suggesting need for additional predictors. ${ }^{222-225}$ A study of cancer patients treated with either tinzaparin or warfarin demonstrated that elevated pre-anticoagulant TF levels $(>64.6 \mathrm{pg} / \mathrm{ml})$ and C-reactive protein (CRP; > $75 \mathrm{mg} / \mathrm{l}$ ) increased risk of recurrent VTE (sHR, 3.4; 95\% CI, 2.1-5.5; sHR, 2.3; $95 \%$ CI, 1.2-4.4). ${ }^{225}$ Another study of cancer patients on low molecular weight heparin for 6 months showed that pre-anticoagulant soluble P-selectin (>136 ng/ml) but not D-dimer $(>4.0 \mu \mathrm{g} / \mathrm{ml}$ ) levels increased risk of recurrent VTE (sHR, 4.4, 95\% CI 1.3-16; sHR 2.5, 95\% CI 0.76-7.9) ${ }^{226}$ Elevated CRP (>4.5 mg/l) 21-days after 3 months of low molecular weight heparin treatment was also associated with increased risk for recurrent VTE (sHR 9.8,; 95\% CI 1.86-51.7). ${ }^{227}$ Similarly, elevated D-dimer, as determined by ROC curve analysis ( $>600 \mathrm{ng} / \mathrm{ml}$ ) and age adjustment (>age*10 $\mathrm{ng} / \mathrm{ml}$ ) at 21days post-anticoagulation increased risk of recurrent VTE (sHR 5.81, 95\% CI 1.06-31.72; sHR 5.11, 95\% CI 1.03225.3). ${ }^{227}$ However, precision of estimated effects of CRP and D-dimer with VTE risk are low.

\section{Biomarkers in Primary ATE Risk}

Currently, no risk models are available for primary arterial thromboembolism and biomarker studies are sparse. Elevated neutrophil counts $\left(>4.9 \times 10^{9} / \mathrm{l}\right)$ and soluble P-selectin levels ( $>46.3 \mathrm{ng} / \mathrm{ml}$ ) have been shown to increase arterial thromboembolic risk (sHR 2.4, 95\% CI 1.3-4.6; sHR 2.1, 95\% CI 1.2-3.8). ${ }^{228}$ However, D-dimer, NLR, platelet-to-lymphocyte ratio, $\mathrm{H} 3 \mathrm{Cit}$, cfDNA, and nucleosome levels failed to show significance. ${ }^{114,228,229}$

\section{Future Directions and Considerations}

Improvements in understanding CAT and its mechanisms have opened up a variety of potential biomarker targets for improving risk models and clinical decision making. While $\mathrm{TF}$ and $\mathrm{TF}^{+} \mathrm{EV}$ have been extensively studied, research on NET-related proteins, polyphosphate, podoplanin, and miRNAs has just begun. Currently, risk models exist for predicting primary and recurrent VTE, but few have studied risk models and biomarkers for arterial thromboembolism - the other component of CAT. Furthermore, the role of biomarkers in guiding duration of treatment and predicting bleeding complications from anticoagulation has yet to be assessed. However, selection of candidate biomarkers must also balance predictive potential with clinical feasibility to ensure usage of the biomarker in practice. Awareness of these challenges can advance biomarker study to generate improved risk tools for CAT.

\section{Acknowledgements}

This work was supported by the U01 HL143402 research grant to KRM and AAK from the National Heart, Lung and Blood Institute CLOT Consortium, as well as the North American Society on Thrombosis and Hemostasis/ Hemostasis and Thrombosis Research Society research fellowship to ASK. AAK additionally acknowledges 
research support from the Sondra and Stephen Hardis Chair in Oncology Research. All authors have read and approve the journal's authorship agreement and policy on disclosure of potential conflicts of interest. The authors declare no conflicts of interest. No sources of editorial support were used in preparation of this manuscript.

\section{Abbreviations}

$\begin{array}{ll}\text { ADP } & \text { adenosine diphosphate } \\ \text { ATE } & \text { arterial thromboembolism } \\ \text { CAT } & \text { cancer-associated thrombosi } \\ \text { CBC } & \text { complete blood count } \\ \text { CCL3 } & \text { chemokine ligand 3 } \\ \text { CD40L } & \text { CD40 ligand } \\ \text { cfDNA } & \text { cell free DNA } \\ \text { CI } & \text { confidence interval } \\ \text { CLEC-2 } & \text { C-type lectin-like receptor 2 } \\ \text { CRP } & \text { C-reactive protein } \\ \text { DDU } & \text { D-dimer unit }\end{array}$

ELFA

enzyme-linked immunofluorescence assay

ELISA

enzyme-linked immunosorbent assay

ELISPOT

enzyme linked immune spot assays

ERCC

Extracellular RNA Communication Consortium

EV

extracellular vesicle

FEU

fibrinogen equivalent unit

G-CSF granulocyte-colony stimulating factor

GPIb glycoprotein Ib

GPIIb/IIIa

glycoprotein IIb/IIIa

H3Cit

citrullinated histone $\mathrm{H} 3$

HK

high molecular weight kininogen

HR

hazard ratio

IDH1

isocitrate dehydrogenase 1

IL interleukin

ISEV

International Society for Extracellular Vesicles 


\begin{tabular}{ll} 
miRNA & microRNA \\
mRNA & messenger RNA \\
NET & neutrophil extracellular trap \\
NLR & neutrophil-to-lymphocyte ratio \\
OR & odds ratio \\
PAI-1 & plasminogen activator inhibitor-1 \\
PAR1 & protease-activated receptor 1 \\
PAR4 & protease-activated receptor 4 \\
PCR & polymerase chain reaction \\
PK & prekallikrein \\
polyP & polyphosphate \\
qRT-PCR & quantitative reverse transcription polymerase chain reaction \\
ROC & receiver operating characteristic \\
SHR & subdistribution hazard ratio \\
TF & tissue factor \\
TF & tissue factor-positive extracellular vesicle \\
TNF-a & tumor necrosis factor-a \\
TxA2 & vascular endothelial growth factor \\
VEGF & venous thromboembolism \\
VTE & von Willebrand factor \\
vWF & \\
\hline
\end{tabular}

\section{References}

1. Khorana AA, Francis CW, Culakova E, Kuderer NM, Lyman GH. Thromboembolism is a leading cause of death in cancer patients receiving outpatient chemotherapy. J Thromb Haemost. 2007;5(3):632-634. doi:10.1111/j.1538-7836.2007.02374.x [PubMed: 17319909]

2. Heit JA, Silverstein MD, Mohr DN, Petterson TM, O'Fallon WM, Melton LJ. Risk Factors for Deep Vein Thrombosis and Pulmonary Embolism: A Population-Based Case-Control Study. Arch Intern Med. 2000;160(6):809-815. doi:10.1001/archinte.160.6.809 [PubMed: 10737280]

3. Blom JW, Doggen CJM, Osanto S, Rosendaal FR. Malignancies, prothrombotic mutations, and the risk of venous thrombosis. JAMA. 2005;293(6):715-722. doi:10.1001/jama.293.6.715 [PubMed: 15701913]

4. Grilz E, Königsbrügge O, Posch F, et al. Frequency, risk factors, and impact on mortality of arterial thromboembolism in patients with cancer. Haematologica. 2018;103(9):1549-1556. doi:10.3324/ haematol.2018.192419 [PubMed: 29794142] 
5. Navi BB, Reiner AS, Kamel H, et al. Risk of Arterial Thromboembolism in Patients With Cancer. Journal of the American College of Cardiology. 2017;70(8):926-938. doi:10.1016/ j.jacc.2017.06.047 [PubMed: 28818202]

6. Scarvelis D, Anderson J, Davis L, et al. Hospital mortality due to pulmonary embolism and an evaluation of the usefulness of preventative interventions. Thromb Res. 2010;125(2):166-170. doi:10.1016/j.thromres.2009.06.025 [PubMed: 19647292]

7. Prandoni P, Lensing AWA, Piccioli A, et al. Recurrent venous thromboembolism and bleeding complications during anticoagulant treatment in patients with cancer and venous thrombosis. Blood. 2002;100(10):3484-3488. doi:10.1182/blood-2002-01-0108 [PubMed: 12393647]

8. Wun T, White RH. Epidemiology of cancer-related venous thromboembolism. Best Practice \& Research Clinical Haematology. 2009;22(1):9-23. doi:10.1016/j.beha.2008.12.001 [PubMed: 19285269]

9. Khorana AA, Kuderer NM, Culakova E, Lyman GH, Francis CW. Development and validation of a predictive model for chemotherapy-associated thrombosis. Blood. 2008;111(10):4902-4907. doi:10.1182/blood-2007-10-116327 [PubMed: 18216292]

10. Ay C, Dunkler D, Marosi C, et al. Prediction of venous thromboembolism in cancer patients. Blood. 2010;116(24):5377-5382. doi:10.1182/blood-2010-02-270116 [PubMed: 20829374]

11. Verso M, Agnelli G, Barni S, Gasparini G, LaBianca R. A modified Khorana risk assessment score for venous thromboembolism in cancer patients receiving chemotherapy: the Protecht score. Intern Emerg Med. 2012;7(3):291-292. doi:10.1007/s11739-012-0784-y [PubMed: 22547369]

12. Pelzer U, Sinn M, Stieler J, Riess H. [Primary pharmacological prevention of thromboembolic events in ambulatory patients with advanced pancreatic cancer treated with chemotherapy?]. Dtsch Med Wochenschr. 2013;138(41):2084-2088. doi:10.1055/s-0033-1349608 [PubMed: 24085361]

13. Cella CA, Minno GD, Carlomagno C, et al. Preventing Venous Thromboembolism in Ambulatory Cancer Patients: The ONKOTEV Study. The Oncologist. 2017;22(5):601-608. doi:10.1634/ theoncologist.2016-0246 [PubMed: 28424324]

14. Gerotziafas GT, Taher A, Abdel-Razeq H, et al. A Predictive Score for Thrombosis Associated with Breast, Colorectal, Lung, or Ovarian Cancer: The Prospective COMPASS-Cancer-Associated Thrombosis Study. The Oncologist. 2017;22(10):1222-1231. doi:10.1634/ theoncologist.2016-0414 [PubMed: 28550032]

15. Martín AJM, Ortega I, Font C, et al. Multivariable clinical-genetic risk model for predicting venous thromboembolic events in patients with cancer. British Journal of Cancer. 2018;118(8):1056. doi:10.1038/s41416-018-0027-8 [PubMed: 29588512]

16. Pabinger I, van Es N, Heinze G, et al. A clinical prediction model for cancer-associated venous thromboembolism: a development and validation study in two independent prospective cohorts. The Lancet Haematology. 2018;5(7):e289-e298. doi:10.1016/S2352-3026(18)30063-2 [PubMed: 29885940]

17. Louzada Martha L, Carrier Marc, Lazo-Langner Alejandro, et al. Development of a Clinical Prediction Rule for Risk Stratification of Recurrent Venous Thromboembolism in Patients With Cancer-Associated Venous Thromboembolism. Circulation. 2012;126(4):448-454. doi:10.1161/ CIRCULATIONAHA.111.051920 [PubMed: 22679142]

18. Jain KK. The Handbook of Biomarkers. Second edition. Humana Press; 2017.

19. Khorana AA. Simplicity versus complexity: an existential dilemma as risk tools evolve. The Lancet Haematology. 2018;5(7):e273-e274. doi:10.1016/S2352-3026(18)30067-X [PubMed: 29885941]

20. Mahajan A, Brunson A, White R, Wun T. The Epidemiology of Cancer-Associated Venous Thromboembolism: An Update. Seminars in Thrombosis and Hemostasis. 2019;45(04):321-325. doi:10.1055/s-0039-1688494 [PubMed: 31041801]

21. Abdol Razak NB, Jones G, Bhandari M, Berndt MC, Metharom P. Cancer-Associated Thrombosis: An Overview of Mechanisms, Risk Factors, and Treatment. Cancers (Basel). 2018;10(10). doi:10.3390/cancers10100380

22. Fernandes CJ, Morinaga LTK, Alves JL, et al. Cancer-associated thrombosis: the when, how and why. European Respiratory Review. 2019;28(151). doi:10.1183/16000617.0119-2018 
23. Kimpton M, Carrier M. What's new in the prevention and treatment of cancer-associated thrombosis? Hematology Am Soc Hematol Educ Program. 2019;2019(1):158-166. doi:10.1182/ hematology.2019000023 [PubMed: 31808858]

24. Wang T-F, Li A, Garcia D. Managing thrombosis in cancer patients. Research and Practice in Thrombosis and Haemostasis. 2018;2(3):429-438. doi:10.1002/rth2.12102 [PubMed: 30046747]

25. Théry C, Witwer KW, Aikawa E, et al. Minimal information for studies of extracellular vesicles 2018 (MISEV2018): a position statement of the International Society for Extracellular Vesicles and update of the MISEV2014 guidelines. Journal of Extracellular Vesicles. 2018;7(1):1535750. doi:10.1080/20013078.2018.1535750

26. Dvorak HF, Quay SC, Orenstein NS, et al. Tumor shedding and coagulation. Science. 1981;212(4497):923-924. doi:10.1126/science.7195067 [PubMed: 7195067]

27. Rak J Microparticles in Cancer. Semin Thromb Hemost. 2010;36(08):888-906. doi:10.1055/ s-0030-1267043 [PubMed: 21049390]

28. Shah R, Patel T, Freedman JE. Circulating Extracellular Vesicles in Human Disease. New England Journal of Medicine. 2018;379(10):958-966. doi:10.1056/NEJMra1704286

29. Olivier Morel, Laurence Jesel, Freyssinet Jean-Marie Toti Florence. Cellular Mechanisms Underlying the Formation of Circulating Microparticles. Arteriosclerosis, Thrombosis, and Vascular Biology. 2011;31(1):15-26. doi:10.1161/ATVBAHA.109.200956

30. Suzuki J, Umeda M, Sims PJ, Nagata S. Calcium-dependent phospholipid scrambling by TMEM16F. Nature. 2010;468(7325):834-838. doi:10.1038/nature09583 [PubMed: 21107324]

31. Fujii T, Sakata A, Nishimura S, Eto K, Nagata S. TMEM16F is required for phosphatidylserine exposure and microparticle release in activated mouse platelets. PNAS. 2015;112(41):1280012805. doi:10.1073/pnas.1516594112 [PubMed: 26417084]

32. Malhotra OP, Nesheim ME, Mann KG. The kinetics of activation of normal and gammacarboxyglutamic acid-deficient prothrombins. J Biol Chem. 1985;260(1):279-287. [PubMed: 2578125]

33. Thaler J, Ay C, Weinstabl H, et al. Circulating procoagulant microparticles in cancer patients. Ann Hematol. 2011;90(4):447-453. doi:10.1007/s00277-010-1111-1 [PubMed: 20981426]

34. Yuana Y, Bertina RM, Osanto S. Pre-analytical and analytical issues in the analysis of blood microparticles. Thromb Haemost. 2011;105(03):396-408. doi:10.1160/TH10-09-0595 [PubMed: 21174005]

35. Mooberry MJ, Key NS. Microparticle analysis in disorders of hemostasis and thrombosis. Cytometry Part A. 2016;89(2):111-122. doi:10.1002/cyto.a.22647

36. Extracellular RNA Communication Consortium. exRNA Protocols. exRNA Portal. Accessed May 13, 2020. https://exrna.org/resources/protocols/

37. Egorina Elena M, Sovershaev Mikhail A, Bjørkøy Geir, et al. Intracellular and Surface Distribution of Monocyte Tissue Factor. Arteriosclerosis, Thrombosis, and Vascular Biology. 2005;25(7):14931498. doi:10.1161/01.ATV.0000168413.29874.d7

38. Gregory SA, Morrissey JH, Edgington TS. Regulation of tissue factor gene expression in the monocyte procoagulant response to endotoxin. Molecular and Cellular Biology. 1989;9(6):27522755. doi:10.1128/MCB.9.6.2752 [PubMed: 2503712]

39. Franco RF, de Jonge E, Dekkers PEP, et al. The in vivo kinetics of tissue factor messenger RNA expression during human endotoxemia: relationship with activation of coagulation. Blood. 2000;96(2):554-559. doi:10.1182/blood.V96.2.554 [PubMed: 10887118]

40. Bode M, Mackman N. Regulation of tissue factor gene expression in monocytes and endothelial cells: Thromboxane A2 as a new player. Vascular Pharmacology. 2014;62(2):57-62. doi:10.1016/ j.vph.2014.05.005 [PubMed: 24858575]

41. Collier MEW, Akinmolayan A, Goodall AH. Comparison of tissue factor expression and activity in foetal and adult endothelial cells. Blood Coagul Fibrinolysis. 2017;28(6):452-459. doi:10.1097/ MBC.0000000000000621 [PubMed: 28151805]

42. Dvorak HF, DeWater LV, Bitzer AM, et al. Procoagulant Activity Associated with Plasma Membrane Vesicles Shed by Cultured Tumor Cells. Cancer Res. 1983;43(9):4434-4442. [PubMed: 6347372] 
43. Yu JL, May L, Lhotak V, et al. Oncogenic events regulate tissue factor expression in colorectal cancer cells: implications for tumor progression and angiogenesis. Blood. 2005;105(4):1734-1741. doi:10.1182/blood-2004-05-2042 [PubMed: 15494427]

44. Davila M, Amirkhosravi A, Coll E, et al. Tissue factor-bearing microparticles derived from tumor cells: impact on coagulation activation. Journal of Thrombosis and Haemostasis. 2008;6(9):15171524. doi:10.1111/j.1538-7836.2008.02987.x [PubMed: 18433463]

45. Thomas GM, Panicot-Dubois L, Lacroix R, Dignat-George F, Lombardo D, Dubois C. Cancer cell-derived microparticles bearing P-selectin glycoprotein ligand 1 accelerate thrombus formation in vivo. J Exp Med. 2009;206(9):1913-1927. doi:10.1084/jem.20082297 [PubMed: 19667060]

46. Wang J-G, Geddings JE, Aleman MM, et al. Tumor-derived tissue factor activates coagulation and enhances thrombosis in a mouse xenograft model of human pancreatic cancer. Blood. 2012;119(23):5543-5552. doi:10.1182/blood-2012-01-402156 [PubMed: 22547577]

47. Geddings JE, Hisada Y, Boulaftali Y, et al. Tissue factor-positive tumor microvesicles activate platelets and enhance thrombosis in mice. Journal of Thrombosis and Haemostasis. 2016;14(1):153-166. doi:10.1111/jth.13181 [PubMed: 26516108]

48. Hisada Y, Ay C, Auriemma AC, Cooley BC, Mackman N. Human pancreatic tumors grown in mice-release tissue factor-positive microvesicles that increase venous clot size. Journal of Thrombosis and Haemostasis. 2017;15(11):2208-2217. doi:10.1111/jth.13809 [PubMed: 28834179]

49. Ueno T, Toi M, Koike M, Nakamura S, Tominaga T. Tissue factor expression in breast cancer tissues: its correlation with prognosis and plasma concentration. British Journal of Cancer. 2000;83(2):164-170. doi:10.1054/bjoc.2000.1272 [PubMed: 10901365]

50. Tilley RE, Holscher T, Belani R, Nieva J, Mackman N. Tissue factor activity is increased in a combined platelet and microparticle sample from cancer patients. Thrombosis Research. 2008;122(5):604-609. doi:10.1016/j.thromres.2007.12.023 [PubMed: 18262600]

51. Hron G, Kollars M, Weber H, et al. Tissue factor-positive microparticles: Cellular origin and association with coagulation activation in patients with colorectal cancer. Thrombosis and Haemostasis. 2007;97(01):119-123. doi:10.1160/TH06-03-0141 [PubMed: 17200778]

52. Tesselaar MET, Romijn FPHTM, Linden IKVD, Prins FA, Bertina RM, Osanto S. Microparticleassociated tissue factor activity: a link between cancer and thrombosis? Journal of Thrombosis and Haemostasis. 2007;5(3):520-527. doi:10.1111/j.1538-7836.2007.02369.x [PubMed: 17166244]

53. Haubold K, Rink M, Spath B, et al. Tissue factor procoagulant activity of plasma microparticles is increased in patients with early-stage prostate cancer. Thrombosis and Haemostasis. 2009;101(06):1147-1155. doi:10.1160/TH08-10-0654 [PubMed: 19492160]

54. Trappenburg MC, van Schilfgaarde M, Bredewold EO, et al. Elevated numbers and altered subsets of procoagulant microparticles in breast cancer patients using endocrine therapy. Thrombosis Research. 2011;127(4):363-369. doi:10.1016/j.thromres.2010.12.015 [PubMed: 21272922]

55. Thaler J, Ay C, Mackman N, et al. Microparticle-associated tissue factor activity, venous thromboembolism and mortality in pancreatic, gastric, colorectal and brain cancer patients. Journal of Thrombosis and Haemostasis. 2012;10(7):1363-1370. doi:10.1111/j.1538-7836.2012.04754.x [PubMed: 22520016]

56. Bharthuar A, Khorana AA, Hutson A, et al. Circulating microparticle tissue factor, thromboembolism and survival in pancreaticobiliary cancers. Thrombosis Research. 2013;132(2):180-184. doi:10.1016/j.thromres.2013.06.026 [PubMed: 23856554]

57. Langer F, Spath B, Haubold K, et al. Tissue factor procoagulant activity of plasma microparticles in patients with cancer-associated disseminated intravascular coagulation. Ann Hematol. 2008;87(6):451-457. doi:10.1007/s00277-008-0446-3 [PubMed: 18292996]

58. Grover Steven P, Mackman Nigel. Tissue Factor. Arteriosclerosis, Thrombosis, and Vascular Biology. 2018;38(4):709-725. doi:10.1161/ATVBAHA.117.309846

59. Zillmann A, Luther T, Müller I, et al. Platelet-Associated Tissue Factor Contributes to the Collagen-Triggered Activation of Blood Coagulation. Biochemical and Biophysical Research Communications. 2001;281(2):603-609. doi:10.1006/bbrc.2001.4399 [PubMed: 11181090] 
60. Siddiqui FA, Desai H, Amirkhosravi A, Amaya M, Francis JL. The presence and release of tissue factor from human platelets. Platelets. 2002;13(4):247-253. doi:10.1080/09537100220146398 [PubMed: 12189027]

61. Müller I, Klocke A, Alex M, et al. Intravascular tissue factor initiates coagulation via circulating microvesicles and platelets. The FASEB Journal. 2003;17(3):476-478. doi:10.1096/fj.02-0574fje [PubMed: 12514112]

62. Marina Camera, Marta Frigerio, Vincenzo Toschi, et al. Platelet Activation Induces Cell-Surface Immunoreactive Tissue Factor Expression, Which Is Modulated Differently by Antiplatelet Drugs. Arteriosclerosis, Thrombosis, and Vascular Biology. 2003;23(9):1690-1696. doi:10.1161/01.ATV.0000085629.23209.AA

63. Panes O, Matus V, Sáez CG, Quiroga T, Pereira J, Mezzano D. Human platelets synthesize and express functional tissue factor. Blood. 2007;109(12):5242-5250. doi:10.1182/ blood-2006-06-030619 [PubMed: 17347408]

64. Butenas S, Bouchard BA, Brummel-Ziedins KE, Parhami-Seren B, Mann KG. Tissue factor activity in whole blood. Blood. 2005;105(7):2764-2770. doi:10.1182/blood-2004-09-3567 [PubMed: 15604222]

65. Bouchard BA, Mann KG, Butenas S. No evidence for tissue factor on platelets. Blood. 2010;116(5):854-855. doi:10.1182/blood-2010-05-285627 [PubMed: 20688968]

66. Bouchard BA, Krudysz-Amblo J, Butenas S. Platelet tissue factor is not expressed transiently after platelet activation. Blood. 2012;119(18):4338-4339. doi:10.1182/blood-2012-01-403469 [PubMed: 22555664]

67. Østerud B, Bouchard BA. Detection of tissue factor in platelets: why is it so troublesome? Platelets. 2019;30(8):957-961. doi:10.1080/09537104.2019.1624708 [PubMed: 31146606]

68. Rauch U, Bonderman D, Bohrmann B, et al. Transfer of tissue factor from leukocytes to platelets is mediated by CD15 and tissue factor. Blood. 2000;96(1):170-175. doi:10.1182/blood.V96.1.170 [PubMed: 10891447]

69. del Conde I, Shrimpton CN, Thiagarajan P, López JA. Tissue-factor-bearing microvesicles arise from lipid rafts and fuse with activated platelets to initiate coagulation. Blood. 2005;106(5):16041611. doi:10.1182/blood-2004-03-1095 [PubMed: 15741221]

70. Sovershaev MA, Egorina EM, Østerud B, Hansen J-B. Evidence for direct transfer of tissue factor from monocytes to platelets in whole blood: Blood Coagulation \& Fibrinolysis. 2012;23(4):345350. doi:10.1097/MBC.0b013e328350bf2f [PubMed: 22343684]

71. Østerud B, Olsen JO. Human platelets do not express tissue factor. Thrombosis Research. 2013;132(1):112-115. doi:10.1016/j.thromres.2013.04.010 [PubMed: 23623171]

72. Tripisciano C, Weiss R, Eichhorn T, et al. Different Potential of Extracellular Vesicles to Support Thrombin Generation: Contributions of Phosphatidylserine, Tissue Factor, and Cellular Origin. Scientific Reports. 2017;7(1):1-11. doi:10.1038/s41598-017-03262-2 [PubMed: 28127051]

73. Waard V de, Hansen HR, Spronk HHM, et al. Differential expression of tissue factor mRNA and protein expression in murine sepsis. Thromb Haemost. 2006;95(02):348-353. doi:10.1160/ TH05-07-0512 [PubMed: 16493499]

74. Egorina EM, Sovershaev MA, Olsen JO, Østerud B. Granulocytes do not express but acquire monocyte-derived tissue factor in whole blood: evidence for a direct transfer. Blood. 2008;111(3):1208-1216. doi:10.1182/blood-2007-08-107698 [PubMed: 17947506]

75. Almeida VH, Rondon AMR, Gomes T, Monteiro RQ. Novel Aspects of Extracellular Vesicles as Mediators of Cancer-Associated Thrombosis. Cells. 2019;8(7):716. doi:10.3390/cells8070716

76. Lacroix R, Vallier L, Bonifay A, et al. Microvesicles and Cancer Associated Thrombosis. Semin Thromb Hemost. 2019;45(06):593-603. doi:10.1055/s-0039-1693476 [PubMed: 31430786]

77. Bang OY, Chung J-W, Lee MJ, et al. Cancer Cell-Derived Extracellular Vesicles Are Associated with Coagulopathy Causing Ischemic Stroke via Tissue Factor-Independent Way: The OASISCANCER Study. PLOS ONE. 2016;11(7):e0159170. doi:10.1371/journal.pone.0159170

78. Konstantin Stark, Irene Schubert, Urjita Joshi, et al. Distinct Pathogenesis of Pancreatic Cancer Microvesicle-Associated Venous Thrombosis Identifies New Antithrombotic Targets In Vivo. Arteriosclerosis, Thrombosis, and Vascular Biology. 2018;38(4):772-786. doi:10.1161/ ATVBAHA.117.310262 
79. Auwerda J, Yuana Y, Osanto S, et al. Microparticle-associated tissue factor activity and venous thrombosis in multiple myeloma. Thrombosis and Haemostasis. 2011;105(01):14-20. doi:10.1160/ TH10-03-0187 [PubMed: 21057704]

80. van Es N, Hisada Y, Di Nisio M, et al. Extracellular vesicles exposing tissue factor for the prediction of venous thromboembolism in patients with cancer: A prospective cohort study. Thrombosis Research. 2018;166:54-59. doi:10.1016/j.thromres.2018.04.009 [PubMed: 29656167]

81. Faille D, Bourrienne M-C, de Raucourt E, et al. Biomarkers for the risk of thrombosis in pancreatic adenocarcinoma are related to cancer process. Oncotarget. 2018;9(41):26453-26465. doi:10.18632/oncotarget.25458 [PubMed: 29899870]

82. Cui C, Wang G, Yang S, Huang S, Qiao R, Cui W. Tissue Factor-bearing MPs and the risk of venous thrombosis in cancer patients: A meta-analysis. Scientific Reports. 2018;8(1):1-8. doi:10.1038/s41598-018-19889-8 [PubMed: 29311619]

83. Owens AP, Mackman N. Microparticles in Hemostasis and Thrombosis. Circ Res. 2011;108(10):1284-1297. doi:10.1161/CIRCRESAHA.110.233056 [PubMed: 21566224]

84. Berckmans RJ, Sturk A, van Tienen LM, Schaap MCL, Nieuwland R. Cell-derived vesicles exposing coagulant tissue factor in saliva. Blood. 2011;117(11):3172-3180. doi:10.1182/ blood-2010-06-290460 [PubMed: 21248061]

85. Basavaraj MG, Olsen JO, Østerud B, Hansen J-B. Differential ability of tissue factor antibody cloneson detection of tissue factor in blood cells and microparticles. Thrombosis Research. 2012;130(3):538-546. doi:10.1016/j.thromres.2012.06.001 [PubMed: 22728024]

86. Gardiner C, Harrison P, Belting M, et al. Extracellular vesicles, tissue factor, cancer and thrombosis - discussion themes of the ISEV 2014 Educational Day. Journal of Extracellular Vesicles. 2015;4(1):26901. doi:10.3402/jev.v4.26901 [PubMed: 25773446]

87. Engstad CS, Lia K, Rekdal Ø, Olsen JO, Østeoid B. A novel biological effect of platelet factor 4 (PF4): enhancement of LPS-induced tissue factor activity in monocytes. Journal of Leukocyte Biology. 1995;58(5):575-581. doi:10.1002/jlb.58.5.575 [PubMed: 7595059]

88. Hisada Y, Mackman N. Measurement of tissue factor activity in extracellular vesicles from human plasma samples. Research and Practice in Thrombosis and Haemostasis. 2019;3(1):44-48. doi:10.1002/rth2.12165 [PubMed: 30656275]

89. Brinkmann V, Reichard U, Goosmann C, et al. Neutrophil Extracellular Traps Kill Bacteria. Science. 2004;303(5663):1532-1535. doi:10.1126/science.1092385 [PubMed: 15001782]

90. Gross PL, Furie BC, Merrill-Skoloff G, Chou J, Furie B. Leukocyte-versus microparticle-mediated tissue factor transfer during arteriolar thrombus development. Journal of Leukocyte Biology. 2005;78(6):1318-1326. doi:10.1189/jlb.0405193 [PubMed: 16204641]

91. Darbousset R, Thomas GM, Mezouar S, et al. Tissue factor-positive neutrophils bind to injured endothelial wall and initiate thrombus formation. Blood. 2012;120(10):2133-2143. doi:10.1182/ blood-2012-06-437772 [PubMed: 22837532]

92. Guimarães-Costa AB, Nascimento MTC, Wardini AB, Pinto-da-Silva LH, Saraiva EM. ETosis: A Microbicidal Mechanism beyond Cell Death. Journal of Parasitology Research. Published online 2012. doi: $10.1155 / 2012 / 929743$

93. Fuchs TA, Brill A, Duerschmied D, et al. Extracellular DNA traps promote thrombosis. PNAS. 2010;107(36):15880-15885. doi:10.1073/pnas.1005743107 [PubMed: 20798043]

94. Demers M, Krause DS, Schatzberg D, et al. Cancers predispose neutrophils to release extracellular DNA traps that contribute to cancer-associated thrombosis. PNAS. 2012;109(32):13076-13081. doi:10.1073/pnas.1200419109 [PubMed: 22826226]

95. Laridan E, Martinod K, Meyer SFD. Neutrophil Extracellular Traps in Arterial and Venous Thrombosis. Semin Thromb Hemost. 2019;45(01):086-093. doi:10.1055/s-0038-1677040

96. Martinod K, Demers M, Fuchs TA, et al. Neutrophil histone modification by peptidylarginine deiminase 4 is critical for deep vein thrombosis in mice. PNAS. 2013;110(21):8674-8679. doi:10.1073/pnas.1301059110 [PubMed: 23650392]

97. Semeraro F, Ammollo CT, Morrissey JH, et al. Extracellular histones promote thrombin generatio nhrough platelet-dependent mechanisms: involvement of platelet TLR2 and TLR4. Blood. 2011;118(7):1952-1961. doi:10.1182/blood-2011-03-343061 [PubMed: 21673343] 
98. Brill A, Fuchs TA, Savchenko AS, et al. Neutrophil extracellular traps promote deep vein thrombosis in mice. Journal of Thrombosis and Haemostasis. 2012;10(1):136-144. doi:10.1111/ j.1538-7836.2011.04544.x [PubMed: 22044575]

99. Lam FW, Cruz MA, Parikh K, Rumbaut RE. Histones stimulate von Willebrand factor release in vitro and in vivo. Haematologica. 2016;101(7):e277-e279. doi:10.3324/haematol.2015.140632 [PubMed: 27013650]

100. Elaskalani O, Razak NBA, Metharom P. Neutrophil extracellular traps induce aggregation of washed human platelets independently of extracellular DNA and histones. Cell Commun Signal. 2018;16(1):1-15. doi:10.1186/s12964-018-0235-0 [PubMed: 29329590]

101. Massberg S, Grahl L, von Bruehl M-L, et al. Reciprocal coupling of coagulation and innate immunity via neutrophil serine proteases. Nature Medicine. 2010;16(8):887-896. doi:10.1038/ nm. 2184

102. von Brühl M-L, Stark K, Steinhart A, et al. Monocytes, neutrophils, and platelets cooperate to initiate and propagate venous thrombosis in mice in vivo. J Exp Med. 2012;209(4):819-835. doi:10.1084/jem.20112322 [PubMed: 22451716]

103. Kambas K, Mitroulis I, Apostolidou E, et al. Autophagy Mediates the Delivery of Thrombogenic Tissue Factor to Neutrophil Extracellular Traps in Human Sepsis. PLoS One. 2012;7(9). doi:10.1371/journal.pone.0045427

104. Huang Y-M, Wang H, Wang C, Chen M, Zhao M-H. Promotion of Hypercoagulability in Antineutrophil Cytoplasmic Antibody-Associated Vasculitis by C5a-Induced Tissue FactorExpressing Microparticles and Neutrophil Extracellular Traps. Arthritis \& Rheumatology. 2015;67(10):2780-2790. doi:10.1002/art.39239 [PubMed: 26097236]

105. Stakos DA, Kambas K, Konstantinidis T, et al. Expression of functional tissue factor by neutrophil extracellular traps in culprit artery of acute myocardial infarction. Eur Heart J. 2015;36(22):1405-1414. doi:10.1093/eurheartj/ehv007 [PubMed: 25660055]

106. Wang Y, Luo L, Braun OÖ, et al. Neutrophil extracellular trap-microparticle complexes enhance thrombin generation via the intrinsic pathway of coagulation in mice. Scientific Reports. 2018;8(1):1-14. doi:10.1038/s41598-018-22156-5 [PubMed: 29311619]

107. Thomas GM, Brill A, Mezouar S, et al. Tissue factor expressed by circulating cancer cell-derived microparticles drastically increases the incidence of deep vein thrombosis in mice. Journal of Thrombosis and Haemostasis. 2015;13(7):1310-1319. doi:10.1111/jth.13002 [PubMed: 25955268]

108. Leal AC, Mizurini DM, Gomes T, et al. Tumor-Derived Exosomes Induce the Formation of Neutrophil Extracellular Traps: Implications For The Establishment of Cancer-Associated Thrombosis. Scientific Reports. 2017;7(1):1-12. doi:10.1038/s41598-017-06893-7 [PubMed: 28127051]

109. Hisada Y, Grover SP, Maqsood A, et al. Neutrophils and neutrophil extracellular traps enhance venous thrombosis in mice bearing human pancreatic tumors. Haematologica. 2020;105(1):218225. doi:10.3324/haematol.2019.217083 [PubMed: 31048354]

110. Oklu R, Sheth RA, Wong KHK, Jahromi AH, Albadawi H. Neutrophil extracellular traps are increased in cancer patients but does not associate with venous thrombosis. Cardiovascular Diagnosis and Therapy. 2017;7(3):S140-S149-S149.

111. Thålin C, Demers M, Blomgren B, et al. NETosis promotes cancer-associated arterial microthrombosis presenting as ischemic stroke with troponin elevation. Thrombosis Research. 2016;139:56-64. doi:10.1016/j.thromres.2016.01.009 [PubMed: 26916297]

112. Mauracher L-M, Posch F, Martinod K, et al. Citrullinated histone H3, a biomarker of neutrophil extracellular trap formation, predicts the risk of venous thromboembolism in cancer patients. Journal of Thrombosis and Haemostasis. 2018;16(3):508-518. doi:10.1111/jth.13951 [PubMed: 29325226]

113. Ferroni P, Riondino S, Formica V, et al. Venous thromboembolism risk prediction in ambulatory cancer patients: Clinical significance of neutrophil/lymphocyte ratio and platelet/lymphocyte ratio. International Journal of Cancer. 2015;136(5):1234-1240. doi:10.1002/ijc.29076 [PubMed: 25042739] 
114. Grilz E, Posch F, Königsbrügge O, et al. Association of Platelet-to-Lymphocyte Ratio and Neutrophil-to-Lymphocyte Ratio with the Risk of Thromboembolism and Mortality in Patients with Cancer. Thromb Haemost. 2018;118(11):1875-1884. doi:10.1055/s-0038-1673401 [PubMed: 30296815]

115. Fuentes HE, Paz LH, Wang Y, Oramas DM, Simons CR, Tafur AJ. Performance of Current Thromboembolism Risk Assessment Tools in Patients With Gastric Cancer and Validity After First Treatment. Clin Appl Thromb Hemost. 2018;24(5):790-796. doi:10.1177/1076029617726599 [PubMed: 28884610]

116. Thålin C, Daleskog M, Göransson SP, et al. Validation of an enzyme-linked immunosorbent assay for the quantification of citrullinated histone $\mathrm{H} 3$ as a marker for neutrophil extracellular traps in human plasma. Immunol Res. 2017;65(3):706-712. doi:10.1007/s12026-017-8905-3 [PubMed: 28161762]

117. Szotowski Björn Antoniak Silvio, Wolfgang Poller, Schultheiss Heinz-Peter Rauch Ursula. Procoagulant Soluble Tissue Factor Is Released From Endothelial Cells in Response to Inflammatory Cytokines. Circulation Research. 2005;96(12):1233-1239. doi:10.1161/01.RES.0000171805.24799.fa [PubMed: 15920023]

118. Puhlmann M, Weinreich DM, Farma JM, Carroll NM, Turner EM, Alexander HR. Interleukin-1 $\beta$ induced vascular permeability is dependent on induction of endothelial Tissue Factor (TF) activity. Journal of Translational Medicine. 2005;3(1). doi:10.1186/1479-5876-3-37 [PubMed: 15659244]

119. Gieseler F, Plattfaut C, Quecke T, Freund A, Ungefroren H, Ender F. Heterogeneity of microvesicles from cancer cell lines under inflammatory stimulation with TNF-a. Cell Biology International. 2018;42(11):1533-1544. doi:10.1002/cbin.11040 [PubMed: 30080276]

120. van Hinsbergh V, Kooistra T, van den Berg E, Princen H, Fiers W, Emeis J. Tumor necrosis factor increases the production of plasminogen activator inhibitor in human endothelial cells in vitro and in rats in vivo. Blood. 1988;72(5):1467-1473. doi:10.1182/ blood.V72.5.1467.bloodjournal7251467 [PubMed: 3140909]

121. van Hinsbergh VW, Bauer KA, Kooistra T, et al. Progress of fibrinolysis during tumor necrosis factor infusions in humans. Concomitant increase in tissue-type plasminogen activator, plasminogen activator inhibitor type-1, and fibrin(ogen) degradation products. Blood. 1990;76(11):2284-2289. doi:10.1182/blood.V76.11.2284.2284 [PubMed: 1701665]

122. Lindemann S, Tolley ND, Dixon DA, et al. Activated platelets mediate inflammatory signaling by regulated interleukin $1 \beta$ synthesis. J Cell Biol. 2001;154(3):485-490. doi:10.1083/jcb.200105058 [PubMed: 11489912]

123. Brown GT, Narayanan P, Li W, Silverstein RL, McIntyre TM. Lipopolysaccharide Stimulates Platelets through an IL-1 $\beta$ Autocrine Loop. The Journal of Immunology. 2013;191(10):51965203. doi:10.4049/jimmunol.1300354 [PubMed: 24081990]

124. Qi J, Kreutzer DL. Fibrin activation of vascular endothelial cells. Induction of IL-8 expression. The Journal of Immunology. 1995;155(2):867-876. [PubMed: 7608564]

125. Lalla RV, Goralnick SJ, Tanzer ML, Kreutzer DL. Fibrin induces IL-8 expression from human oral squamous cell carcinoma cells. Oral Oncology. 2001;37(3):234-242. doi:10.1016/ S1368-8375(00)00090-7 [PubMed: 11287277]

126. Alfaro C, Teijeira A, Oñate C, et al. Tumor-Produced Interleukin-8 Attracts Human MyeloidDerived Suppressor Cells and Elicits Extrusion of Neutrophil Extracellular Traps (NETs). Clin Cancer Res. 2016;22(15):3924-3936. doi:10.1158/1078-0432.CCR-15-2463 [PubMed: 26957562]

127. Mechtcheriakova D, Wlachos A, Holzmüller H, Binder BR, Hofer E. Vascular Endothelial Cell Growth Factor-Induced Tissue Factor Expression in Endothelial Cells Is Mediated by EGR-1. Blood. 1999;93(11):3811-3823. doi:10.1182/blood.V93.11.3811 [PubMed: 10339488]

128. Abe K, Shoji M, Chen J, et al. Regulation of vascular endothelial growth factor production and angiogenesis by the cytoplasmic tail of tissue factor. PNAS. 1999;96(15):8663-8668. doi:10.1073/pnas.96.15.8663 [PubMed: 10411932]

129. Matsuo K, Hasegawa K, Yoshino K, et al. Venous thromboembolism, interleukin-6 and survival outcomes in patients with advanced ovarian clear cell carcinoma. European Journal of Cancer. 2015;51(14):1978-1988. doi:10.1016/j.ejca.2015.07.012 [PubMed: 26238017] 
130. Lim SH, Woo S, Kim S, Ko YH, Kim WS, Kim SJ. Cross-sectional Study of Patients with Diffuse Large B-Cell Lymphoma: Assessing the Effect of Host Status, Tumor Burden, and Inflammatory Activity on Venous Thromboembolism. Cancer Res Treat. 2016;48(1):312-321. doi:10.4143/ crt.2014.266 [PubMed: 25761485]

131. Reitter E-M, Ay C, Kaider A, et al. Interleukin levels and their potential association with venous thromboembolism and survival in cancer patients. Clinical \& Experimental Immunology. 2014;177(1):253-260. doi:10.1111/cei.12308

132. Mir Seyed Nazari P, Marosi C, Moik F, et al. Low Systemic Levels of Chemokine C-C Motif Ligand 3 (CCL3) are Associated with a High Risk of Venous Thromboembolism in Patients with Glioma. Cancers. 2019;11(12):2020. doi:10.3390/cancers11122020

133. Ferroni P, Riondino S, Portarena I, et al. Association between increased tumor necrosis factor alpha levels and acquired activated protein $\mathrm{C}$ resistance in patients with metastatic colorectal cancer. Int J Colorectal Dis. 2012;27(12):1561-1567. doi:10.1007/s00384-012-1493-8 [PubMed: 22581210]

134. Posch F, Thaler J, Zlabinger G-J, et al. Soluble Vascular Endothelial Growth Factor (sVEGF) and the Risk of Venous Thromboembolism in Patients with Cancer: Results from the Vienna Cancer and Thrombosis Study (CATS). Clinical Cancer Research. 2016;22(1):200-206. doi:10.1158/1078-0432.CCR-14-3358 [PubMed: 26302981]

135. Stenken JA, Poschenrieder AJ. Bioanalytical Chemistry of Cytokines-A Review. Anal Chim Acta. 2015;853:95-115. doi:10.1016/j.aca.2014.10.009 [PubMed: 25467452]

136. Zhou X, Fragala MS, McElhaney JE, Kuchel GA. Conceptual and methodological issues relevant to cytokine and inflammatory marker measurements in clinical research. Curr Opin Clin Nutr Metab Care. 2010;13(5):541-547. doi:10.1097/MCO.0b013e32833cf3bc [PubMed: 20657280]

137. Hennø LT, Storjord E, Christiansen D, et al. Effect of the anticoagulant, storage time and temperature of blood samples on the concentrations of 27 multiplex assayed cytokines Consequences for defining reference values in healthy humans. Cytokine. 2017;97:86-95. doi:10.1016/j.cyto.2017.05.014 [PubMed: 28595117]

138. Suzuki-Inoue K, Osada M, Ozaki Y. Physiologic and pathophysiologic roles of interaction between C-type lectin-like receptor 2 and podoplanin: partners from in utero to adulthood. Journal of Thrombosis and Haemostasis. 2017;15(2):219-229. doi:10.1111/jth.13590 [PubMed: 27960039]

139. Takemoto A, Miyata K, Fujita N. Platelet-activating factor podoplanin: from discovery to drug development. Cancer Metastasis Rev. 2017;36(2):225-234. doi:10.1007/s10555-017-9672-2 [PubMed: 28674748]

140. Lavallée V-P, Chagraoui J, MacRae T, et al. Transcriptomic landscape of acute promyelocytic leukemia reveals aberrant surface expression of the platelet aggregation agonist Podoplanin. Leukemia. 2018;32(6):1349-1357. doi:10.1038/s41375-018-0069-1 [PubMed: 29550835]

141. Suzuki-Inoue K, Kato Y, Inoue O, et al. Involvement of the Snake Toxin Receptor CLEC-2, in Podoplanin-mediated Platelet Activation, by Cancer Cells. J Biol Chem. 2007;282(36):2599326001. doi:10.1074/jbc.M702327200 [PubMed: 17616532]

142. Kato Y, Kaneko MK, Kunita A, et al. Molecular analysis of the pathophysiological binding of the platelet aggregation-inducing factor podoplanin to the C-type lectin-like receptor CLEC-2. Cancer Science. 2008;99(1):54-61. doi:10.1111/j.1349-7006.2007.00634.x [PubMed: 17944973]

143. Riedl J, Preusser M, Nazari PMS, et al. Podoplanin expression in primary brain tumors induces platelet aggregation and increases risk of venous thromboembolism. Blood. 2017;129(13):18311839. doi:10.1182/blood-2016-06-720714 [PubMed: 28073783]

144. Mege D, Panicot-Dubois L, Ouaissi M, et al. The origin and concentration of circulating microparticles differ according to cancer type and evolution: A prospective single-center study. International Journal of Cancer. 2016;138(4):939-948. doi:10.1002/ijc.29837 [PubMed: 26341361]

145. Shirai T, Inoue O, Tamura S, et al. C-type lectin-like receptor 2 promotes hematogenous tumor metastasis and prothrombotic state in tumor-bearing mice. Journal of Thrombosis and Haemostasis. 2017;15(3):513-525. doi:10.1111/jth.13604 [PubMed: 28028907] 
146. Payne H, Ponomaryov T, Watson SP, Brill A. Mice with a deficiency in CLEC-2 are protected against deep vein thrombosis. Blood. 2017;129(14):2013-2020. doi:10.1182/ blood-2016-09-742999 [PubMed: 28104688]

147. Unruh D, Schwarze SR, Khoury L, et al. Mutant IDH1 and thrombosis in gliomas. Acta Neuropathol. 2016;132(6):917-930. doi:10.1007/s00401-016-1620-7 [PubMed: 27664011]

148. Unruh D, Mirkov S, Wray B, et al. Methylation-dependent Tissue Factor Suppression Contributes to the Reduced Malignancy of IDH1-mutant Gliomas. Clin Cancer Res. 2019;25(2):747-759. doi:10.1158/1078-0432.CCR-18-1222 [PubMed: 30266764]

149. Unruh D, Zewde M, Buss A, et al. Methylation and transcription patterns are distinct in IDH mutant gliomas compared to other IDH mutant cancers. Scientific Reports. 2019;9(1):1-11. doi:10.1038/s41598-019-45346-1 [PubMed: 30626917]

150. Nazari PMS, Riedl J, Preusser M, et al. Combination of isocitrate dehydrogenase 1 (IDH1) mutation and podoplanin expression in brain tumors identifies patients at high or low risk of venous thromboembolism. Journal of Thrombosis and Haemostasis. 2018;16(6):1121-1127. doi:10.1111/jth.14129 [PubMed: 29676036]

151. Watanabe J, Natsumeda M, Okada M, et al. Podoplanin Expression and IDH-Wildtype Status Predict Venous Thromboembolism in Patients with High-Grade Gliomas in the Early Postoperative Period. World Neurosurgery. 2019;128:e982-e988. doi:10.1016/ j.wneu.2019.05.049 [PubMed: 31100523]

152. Gebert LFR, MacRae IJ. Regulation of microRNA function in animals. Nature Reviews Molecular Cell Biology. 2019;20(1):21. doi:10.1038/s41580-018-0045-7 [PubMed: 30108335]

153. O'Brien J, Hayder H, Zayed Y, Peng C. Overview of MicroRNA Biogenesis, Mechanisms of Actions, and Circulation. Front Endocrinol (Lausanne). 2018;9. doi:10.3389/fendo.2018.00402

154. Landry P, Plante I, Ouellet DL, Perron MP, Rousseau G, Provost P. Existence of a microRNA pathway in anucleate platelets. Nature Structural and Molecular Biology. 2009;16(9):961. doi:10.1038/nsmb.1651

155. Risitano A, Beaulieu LM, Vitseva O, Freedman JE. Platelets and platelet-like particles mediate intercellular RNA transfer. Blood. 2012;119(26):6288-6295. doi:10.1182/blood-2011-12-396440 [PubMed: 22596260]

156. Laffont B, Corduan A, Rousseau M, et al. Platelet microparticles reprogram macrophage gene expression and function. Thromb Haemost. 2016;115(02):311-323. doi:10.1160/th15-05-0389 [PubMed: 26333874]

157. Teruel R, Pérez-Sánchez C, Corral J, et al. Identification of miRNAs as potential modulators of tissue factor expression in patients with systemic lupus erythematosus and antiphospholipid syndrome. Journal of Thrombosis and Haemostasis. 2011;9(10):1985-1992. doi:10.1111/ j.1538-7836.2011.04451.x [PubMed: 21794077]

158. Qin J, Liang H, Shi D, et al. A panel of microRNAs as a new biomarkers for the detection of deep vein thrombosis. J Thromb Thrombolysis. 2015;39(2):215-221. doi:10.1007/s11239-014-1131-0 [PubMed: 25244974]

159. Wang X, Sundquist K, Svensson PJ, et al. Association of recurrent venous thromboembolism and circulating microRNAs. Clinical Epigenetics. 2019;11(1):28. doi:10.1186/s13148-019-0627-z [PubMed: 30760335]

160. Kim AS, Kalady MF, DeVecchio J, et al. Identifying miRNA Biomarkers and Predicted Targets Associated with Venous Thromboembolism in Colorectal Cancer Patients. Blood. 2019;134(Supplement_1):3643-3643. doi:10.1182/blood-2019-127585

161. Oto J, Navarro S, Larsen AC, et al. MicroRNAs and Neutrophil Activation Markers Predict Venous Thrombosis in Pancreatic Ductal Adenocarcinoma and Distal Extrahepatic Cholangiocarcinoma. International Journal of Molecular Sciences. 2020;21(3):840. doi:10.3390/ ijms 21030840

162. Pritchard CC, Cheng HH, Tewari M. MicroRNA profiling: approaches and considerations. Nat Rev Genet. 2012;13(5):358-369. doi:10.1038/nrg3198 [PubMed: 22510765]

163. Grasedieck S, Schöler N, Bommer M, et al. Impact of serum storage conditions on microRNA stability. Leukemia. 2012;26(11):2414-2416. doi:10.1038/leu.2012.106 [PubMed: 22504138] 
164. Tanriverdi K, Kucukural A, Mikhalev E, et al. Comparison of RNA isolation and associated methods for extracellular RNA detection by high-throughput quantitative polymerase chain reaction. Analytical Biochemistry. 2016;501:66-74. doi:10.1016/j.ab.2016.02.019 [PubMed: 26969789]

165. Giraldez MD, Spengler RM, Etheridge A, et al. Comprehensive multi-center assessment of small RNA-seq methods for quantitative miRNA profiling. Nature Biotechnology. 2018;36(8):746-757. doi:10.1038/nbt.4183

166. Grasedieck S, Sorrentino A, Langer C, et al. Circulating microRNAs in hematological diseases: principles, challenges, and perspectives. Blood. 2013;121(25):4977-4984. doi:10.1182/ blood-2013-01-480079 [PubMed: 23550041]

167. Das S, Abdel-Mageed AB, Adamidi C, et al. The Extracellular RNA Communication Consortium: Establishing Foundational Knowledge and Technologies for Extracellular RNA Research. Cell. 2019;177(2):231-242. doi:10.1016/j.cell.2019.03.023 [PubMed: 30951667]

168. Rao NN, Gómez-García MR, Kornberg A. Inorganic Polyphosphate: Essential for Growth and Survival. Annual Review of Biochemistry. 2009;78(1):605-647. doi:10.1146/ annurev.biochem.77.083007.093039

169. Smith SA, Choi SH, Davis-Harrison R, et al. Polyphosphate exerts differential effects on blood clotting, depending on polymer size. Blood. 2010;116(20):4353-4359. doi:10.1182/ blood-2010-01-266791 [PubMed: 20709905]

170. Engel R, Brain CM, Paget J, Lionikiene AS, Mutch NJ. Single-chain factor XII exhibits activity when complexed to polyphosphate. Journal of Thrombosis and Haemostasis. 2014;12(9):15131522. doi:10.1111/jth.12663 [PubMed: 25039405]

171. Ruiz FA, Lea CR, Oldfield E, Docampo R. Human Platelet Dense Granules Contain Polyphosphate and Are Similar to Acidocalcisomes of Bacteria and Unicellular Eukaryotes. J Biol Chem. 2004;279(43):44250-44257. doi:10.1074/jbc.M406261200 [PubMed: 15308650]

172. Choi SH, Smith SA, Morrissey JH. Polyphosphate is a cofactor for the activation of factor XI by thrombin. Blood. 2011;118(26):6963-6970. doi:10.1182/blood-2011-07-368811 [PubMed: 21976677]

173. Geng Y, Verhamme IM, Smith SB, et al. The dimeric structure of factor XI and zymogen activation. Blood. 2013;121(19):3962-3969. doi:10.1182/blood-2012-12-473629 [PubMed: 23515926]

174. Smith SA, Mutch NJ, Baskar D, Rohloff P, Docampo R, Morrissey JH. Polyphosphate modulates blood coagulation and fibrinolysis. Proc Natl Acad Sci U S A. 2006;103(4):903-908. doi:10.1073/pnas.0507195103 [PubMed: 16410357]

175. Choi S, Smith S, Morrissey J. Polyphosphate accelerates factor V activation by factor XIa. Thrombosis and Haemostasis. 2015;113(03):599-604. doi:10.1160/TH14-06-0515 [PubMed: 25338662]

176. Smith SA, Morrissey JH. Polyphosphate enhances fibrin clot structure. Blood. 2008;112(7):28102816. doi:10.1182/blood-2008-03-145755 [PubMed: 18544683]

177. Mutch NJ, Engel R, Uitte de Willige S, Philippou H, Ariëns RAS. Polyphosphate modifies the fibrin network and down-regulates fibrinolysis by attenuating binding of tPA and plasminogen to fibrin. Blood. 2010;115(19):3980-3988. doi:10.1182/blood-2009-11-254029 [PubMed: 20228273]

178. Verhoef JJF, Barendrecht AD, Nickel KF, et al. Polyphosphate nanoparticles on the platelet surface trigger contact system activation. Blood. 2017;129(12):1707-1717. doi:10.1182/ blood-2016-08-734988 [PubMed: 28049643]

179. Campello E, Henderson MW, Noubouossie DF, Simioni P, Key NS. Contact System Activation and Cancer: New Insights in the Pathophysiology of Cancer-Associated Thrombosis. Thromb Haemost. 2018;118(2):251-265. doi:10.1160/TH17-08-0596 [PubMed: 29378353]

180. van Montfoort ML, Meijers JCM. Recent insights into the role of the contact pathway in thromboinflammatory disorders. Hematology Am Soc Hematol Educ Program. 2014;2014(1):60-65. doi:10.1182/asheducation.V2014.1.60.3882400 [PubMed: 25696835] 
181. Nickel KF, Ronquist G, Langer F, et al. The polyphosphate-factor XII pathway drives coagulation in prostate cancer-associated thrombosis. Blood. 2015;126(11):1379-1389. doi:10.1182/ blood-2015-01-622811 [PubMed: 26153520]

182. Roeise O, Sivertsen S, Ruud TE, Bouma BN, Stadaas JO, Aasen AO. Studies on components of the contact phase system in patients with advanced gastrointestinal cancer. Cancer. 1990;65(6):1355-1359. doi:10.1002/1097-0142(19900315)65:6<1355::AIDCNCR2820650618>3.0.CO;2-1 [PubMed: 1689607]

183. Battistelli S, Stefanoni M, Lorenzi B, et al. Coagulation Factor Levels in Non-Metastatic Colorectal Cancer Patients. Int J Biol Markers. 2008;23(1):36-41. doi:10.1177/172460080802300106

184. Pan J, Qian Y, Weiser P, et al. Glycosaminoglycans and Activated Contact System in Cancer Patient Plasmas. In: Zhang L, ed. Progress in Molecular Biology and Translational Science. Vol 93. Glycosaminoglycans in Development, Health and Disease. Academic Press; 2010:473-495. doi:10.1016/S1877-1173(10)93020-2 [PubMed: 20807657]

185. Sciacca FL, Ciusani E, Silvani A, et al. Genetic and Plasma Markers of Venous Thromboembolism in Patients with High Grade Glioma. Clin Cancer Res. 2004;10(4):13121317. doi:10.1158/1078-0432.CCR-03-0198 [PubMed: 14977830]

186. Sotiropoulos G, Kotopouli M, Karampela I, et al. Circulating plasminogen activator inhibitor-1 activity: a biomarker for resectable non-small cell lung cancer? J BUON. 2019;24(3):943-954. [PubMed: 31424646]

187. Nomura S, Ito T, Yoshimura H, et al. Evaluation of thrombosis-related biomarkers before and after therapy in patients with multiple myeloma. J Blood Med. 2018;9:1-7. doi:10.2147/ JBM.S147743 [PubMed: 29403323]

188. Andrén-Sandberg Å, Lecander I, Martinsson G, Åstedt B. Peaks in plasma plasminogen activator inhibitor-1 concentration may explain thrombotic events in cases of pancreatic carcinoma. Cancer. 1992;69(12):2884-2887. doi:10.1002/1097-0142(19920615)69:12<2884::AIDCNCR2820691204>3.0.CO;2-S [PubMed: 1591681]

189. Prins MH, Hirsh J. A Critical Review of the Evidence Supporting a Relationship Between Impaired Fibrinolytic Activity and Venous Thromboembolism. Arch Intern Med. 1991;151(9):1721-1731. doi:10.1001/archinte.1991.00400090023006 [PubMed: 1888237]

190. Brodsky SV, Malinowski K, Golightly M, Jesty J, Goligorsky MS. Plasminogen Activator Inhibitor-1 Promotes Formation of Endothelial Microparticles With Procoagulant Potential. Circulation. Published online October 29, 2002. doi:10.1161/01.CIR.0000033972.90653.AF

191. Chen N, Ren M, Li R, et al. Bevacizumab promotes venous thromboembolism through the induction of PAI-1 in a mouse xenograft model of human lung carcinoma. Mol Cancer. 2015;14(1):140. doi:10.1186/s12943-015-0418-x [PubMed: 26215730]

192. Nalluri SR, Chu D, Keresztes R, Zhu X, Wu S. Risk of Venous Thromboembolism With the Angiogenesis Inhibitor Bevacizumab in Cancer Patients: A Meta-analysis. JAMA. 2008;300(19):2277-2285. doi:10.1001/jama.2008.656 [PubMed: 19017914]

193. Rivera J, Lozano ML, Navarro-Nunez L, Vicente V. Platelet receptors and signaling in the dynamics of thrombus formation. Haematologica. 2009;94(5):700-711. doi:10.3324/ haematol.2008.003178 [PubMed: 19286885]

194. Plantureux L, Mège D, Crescence L, Dignat-George F, Dubois C, Panicot-Dubois L. Impacts of Cancer on Platelet Production, Activation and Education and Mechanisms of Cancer-Associated Thrombosis. Cancers. 2018;10(11):441. doi:10.3390/cancers10110441

195. Haemmerle M, Bottsford-Miller J, Pradeep S, et al. FAK regulates platelet extravasation and tumor growth after antiangiogenic therapy withdrawal. J Clin Invest. 2016;126(5):1885-1896. doi:10.1172/JCI85086 [PubMed: 27064283]

196. Boukerche H, Berthier-Vergnes O, Penin F, et al. Human melanoma cell lines differ in their capacity to release ADP and aggregate platelets. British Journal of Haematology. 1994;87(4):763-772. doi:10.1111/j.1365-2141.1994.tb06736.x [PubMed: 7527241]

197. de Leval X, Benoit V, Delarge J, et al. Pharmacological evaluation of the novel thromboxane modulator BM-567 (II/II). Effects of BM-567 on osteogenic sarcoma-cell-induced platelet 
aggregation. Prostaglandins, Leukotrienes and Essential Fatty Acids. 2003;68(1):55-59. doi:10.1016/S0952-3278(02)00235-1

198. Bussolati B, Russo S, Deambrosis I, et al. Expression of CD154 on renal cell carcinomas and effect on cell proliferation, motility and platelet-activating factor synthesis. International Journal of Cancer. 2002;100(6):654-661. doi:10.1002/ijc.10545 [PubMed: 12209602]

199. Sakai H, Suzuki T, Takahashi Y, et al. Upregulation of thromboxane synthase in human colorectal carcinoma and the cancer cell proliferation by thromboxane A2. FEBS Letters. 2006;580(14):3368-3374. doi:10.1016/j.febslet.2006.05.007 [PubMed: 16709411]

200. Nie D, Che M, Zacharek A, et al. Differential Expression of Thromboxane Synthase in Prostate Carcinoma. Am J Pathol. 2004;164(2):429-439. [PubMed: 14742249]

201. Cathcart M-C, Gately K, Cummins R, Kay E, O’Byrne KJ, Pidgeon GP. Examination of thromboxane synthase as a prognostic factor and therapeutic target in non-small cell lung cancer. Mol Cancer. 2011;10(1):25. doi:10.1186/1476-4598-10-25 [PubMed: 21388528]

202. Kajita S, Ruebel KH, Casey MB, Nakamura N, Lloyd RV. Role of COX-2, thromboxane A 2 synthase, and prostaglandin I 2 synthase in papillary thyroid carcinoma growth. Modern Pathology. 2005;18(2):221-227. doi:10.1038/modpathol.3800285 [PubMed: 15475935]

203. Moussa O, Yordy JS, Abol-Enein H, et al. Prognostic and Functional Significance of Thromboxane Synthase Gene Overexpression in Invasive Bladder Cancer. Cancer Res. 2005;65(24):11581-11587. doi:10.1158/0008-5472.CAN-05-1622 [PubMed: 16357168]

204. Oleksowicz L, Bhagwati N, DeLeon-Fernandez M. Deficient Activity of von Willebrand's Factorcleaving Protease in Patients with Disseminated Malignancies. Cancer Res. 1999;59(9):22442250. [PubMed: 10232615]

205. Mojiri A, Stoletov K, Lorenzana Carrillo MA, et al. Functional assessment of von Willebrand factor expression by cancer cells of non-endothelial origin. Oncotarget. 2016;8(8):13015-13029. doi:10.18632/oncotarget.14273

206. Jurasz P, Alonso-Escolano D, Radomski MW. Platelet-cancer interactions: mechanisms and pharmacology of tumour cell-induced platelet aggregation. Br J Pharmacol. 2004;143(7):819826. doi:10.1038/sj.bjp.0706013 [PubMed: 15492016]

207. Contursi A, Sacco A, Grande R, Dovizio M, Patrignani P. Platelets as crucial partners for tumor metastasis: from mechanistic aspects to pharmacological targeting. Cell Mol Life Sci. 2017;74(19):3491-3507. doi:10.1007/s00018-017-2536-7 [PubMed: 28488110]

208. Xu XR, Yousef GM, Ni H. Cancer and platelet crosstalk: opportunities and challenges for aspirin and other antiplatelet agents. Blood. 2018;131(16):1777-1789. doi:10.1182/ blood-2017-05-743187 [PubMed: 29519806]

209. Connolly GC, Khorana AA, Kuderer NM, Culakova E, Francis CW, Lyman GH. Leukocytosis, thrombosis and early mortality in cancer patients initiating chemotherapy. Thrombosis Research. 2010;126(2):113-118. doi:10.1016/j.thromres.2010.05.012 [PubMed: 20684071]

210. Simanek R, Vormittag R, Ay C, et al. High platelet count associated with venous thromboembolism in cancer patients: results from the Vienna Cancer and Thrombosis Study (CATS). Journal of Thrombosis and Haemostasis. 2010;8(1):114-120. doi:10.1111/ j.1538-7836.2009.03680.x [PubMed: 19889150]

211. Stender MT, Frøkjær JB, Larsen TB, Lundbye-Christensen S, Thorlacius-Ussing O. Preoperative Plasma D-Dimer Is a Predictor of Postoperative Deep Venous Thrombosis in Colorectal Cancer Patients: A Clinical, Prospective Cohort Study with One-Year Follow-Up. Diseases of the Colon \& Rectum. 2009;52(3):446-451. doi:10.1007/DCR.0b013e318197e2b2 [PubMed: 19333044]

212. Kodama J, Seki N, Masahiro S, et al. D-dimer level as a risk factor for postoperative venous thromboembolism in Japanese women with gynecologic cancer. Annals of Oncology. 2010;21(8):1651-1656. doi:10.1093/annonc/mdq012 [PubMed: 20129998]

213. Arpaia G, Carpenedo M, Verga M, et al. D-dimer before chemotherapy might predict venous thromboembolism. Blood Coagulation \& Fibrinolysis. 2009;20(3):170-175. doi:10.1097/ MBC.0b013e32831bc2de [PubMed: 19276795]

214. Reitter E-M, Kaider A, Ay C, et al. Longitudinal analysis of hemostasis biomarkers in cancer patients during antitumor treatment. Journal of Thrombosis and Haemostasis. 2016;14(2):294305. doi:10.1111/jth.13218 [PubMed: 26662117] 
215. Ay C, Vormittag R, Dunkler D, et al. D-Dimer and Prothrombin Fragment $1+2$ Predict Venous Thromboembolism in Patients With Cancer: Results From the Vienna Cancer and Thrombosis Study. JCO. 2009;27(25):4124-4129. doi:10.1200/JCO.2008.21.7752

216. Ferroni P, Martini F, Portarena I, et al. Novel High-Sensitive D-Dimer Determination Predicts Chemotherapy-Associated Venous Thromboembolism in Intermediate Risk Lung Cancer Patients. Clinical Lung Cancer. 2012;13(6):482-487. doi:10.1016/j.cllc.2012.03.005 [PubMed: 22591606]

217. Linkins L-A, Lapner ST. Review of D-dimer testing: Good, Bad, and Ugly. International Journal of Laboratory Hematology. 2017;39(S1):98-103. doi:10.1111/ijlh.12665 [PubMed: 28447414]

218. Riley RS, Gilbert AR, Dalton JB, Pai S, McPherson RA. Widely Used Types and Clinical Applications of D-Dimer Assay. Lab Med. 2016;47(2):90-102. doi:10.1093/labmed/lmw001 [PubMed: 27016528]

219. Haase C, Joergensen M, Ellervik C, Joergensen MK, Bathum L. Age- and sex-dependent reference intervals for D-dimer: Evidence for a marked increase by age. Thrombosis Research. 2013;132(6):676-680. doi:10.1016/j.thromres.2013.09.033 [PubMed: 24139507]

220. Kolkhir P, André F, Church MK, Maurer M, Metz M. Potential blood biomarkers in chronic spontaneous urticaria. Clin Exp Allergy. 2017;47(1):19-36. doi:10.1111/cea.12870 [PubMed: 27926978]

221. Ay C, Simanek R, Vormittag R, et al. High plasma levels of soluble P-selectin are predictive of venous thromboembolism in cancer patients: results from the Vienna Cancer and Thrombosis Study (CATS). Blood. 2008;112(7):2703-2708. doi:10.1182/blood-2008-02-142422 [PubMed: 18539899]

222. Exter PL den, Kooiman J, Huisman MV. Validation of the Ottawa prognostic score for the prediction of recurrent venous thromboembolism in patients with cancer-associated thrombosis. Journal of Thrombosis and Haemostasis. 2013;11(5):998-1000. doi:10.1111/jth.12192 [PubMed: 23496788]

223. Ahn S, Lim KS, Lee Y-S, Lee J-L. Validation of the clinical prediction rule for recurrent venous thromboembolism in cancer patients: the Ottawa score. Support Care Cancer. 2013;21(8):23092313. doi:10.1007/s00520-013-1792-9 [PubMed: 23525939]

224. Astruc N, Ianotto J-C, Metges J-P, Lacut K, Delluc A. External validation of the modified Ottawa score for risk stratification of recurrent cancer-associated thrombosis. European Journal of Internal Medicine. 2016;36:e11-e12. doi:10.1016/j.ejim.2016.08.001 [PubMed: 27592403]

225. Khorana AA, Kamphuisen PW, Meyer G, et al. Tissue Factor As a Predictor of Recurrent Venous Thromboembolism in Malignancy: Biomarker Analyses of the CATCH Trial. Journal of Clinical Oncology. 2017;35(10):1078-1085. doi:10.1200/JCO.2016.67.4564 [PubMed: 28029329]

226. van Es N, Louzada M, Carrier M, et al. Predicting the risk of recurrent venous thromboembolism in patients with cancer: A prospective cohort study. Thrombosis Research. 2018;163:41-46. doi:10.1016/j.thromres.2018.01.009 [PubMed: 29353682]

227. Jara-Palomares L, Solier-Lopez A, Elias-Hernandez T, et al. D-dimer and high-sensitivity Creactive protein levels to predict venous thromboembolism recurrence after discontinuation of anticoagulation for cancer-associated thrombosis. British Journal of Cancer. 2018;119(8):915921. doi:10.1038/s41416-018-0269-5 [PubMed: 30318508]

228. Grilz E, Marosi C, Königsbrügge O, et al. Association of complete blood count parameters, ddimer, and soluble P-selectin with risk of arterial thromboembolism in patients with cancer. Journal of Thrombosis and Haemostasis. 2019;17(8):1335-1344. doi:10.1111/jth.14484 [PubMed: 31099477]

229. Grilz E, Mauracher L-M, Posch F, et al. Citrullinated histone H3, a biomarker for neutrophil extracellular trap formation, predicts the risk of mortality in patients with cancer. British Journal of Haematology. 2019;186(2):311-320. doi:10.1111/bjh.15906 [PubMed: 30968400] 


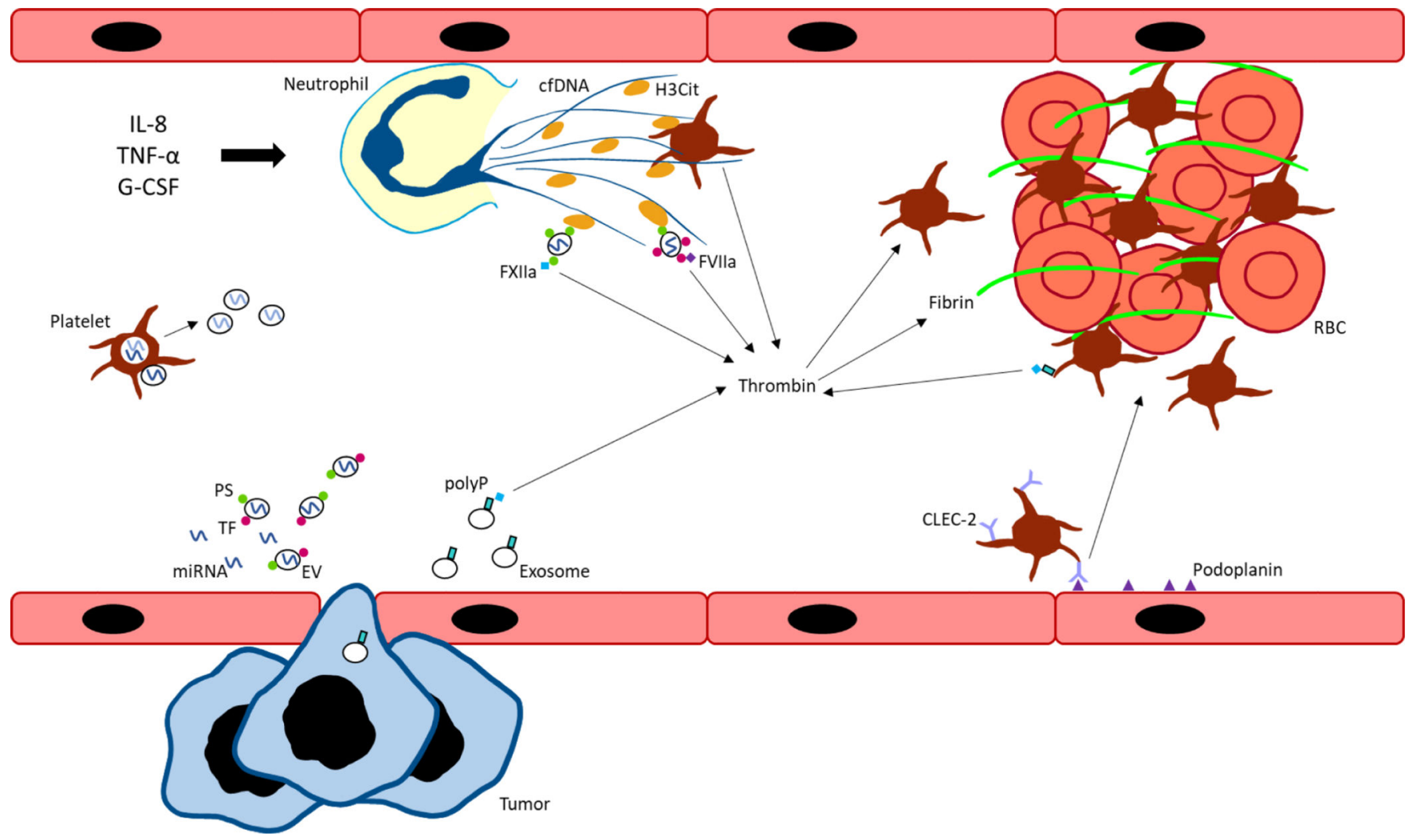

Figure 1. Graphical summary of key mechanisms driving cancer-associated thrombosis. Interleukin-8 (IL-8), tumor necrosis factor-a (TNF- a), and granulocyte-colony stimulating factor (G-CSF) stimulate neutrophils to form neutrophil extracellular traps (NETs) containing cell free DNA (cfDNA) and citrullinated histone H3 (H3Cit). Extracellular vesicles (EVs), derived from tumor or host cells, express negatively charged phosphatidylserine (PS) which bind histones in NETs. EVs also express tissue factor (TF) which binds factor VIIa (FVIIa) to initiate the extrinsic pathway of coagulation and generate thrombin. Tumor cells can also secrete exosomes expressing polyphosphate (polyP) to activate the contact pathway. Similarly, platelets can express polyP to initiate contact pathway activation, as well as interact with cfDNA and histones present in NETs for thrombin and thrombus formation. Podoplanin-expressing activated endothelial cells can bind C-type lectin-like receptor 2 (CLEC-2) on platelets to induce platelet activation and aggregation. Inhibitory microRNAs (miRNAs) can be secreted extracellularly in a proteinor EV-bound form. Platelets and other host cells can take up miRNAs which regulate gene expression of coagulation factors and re-secrete miRNAs into plasma. FXIIa, factor XIIa; $\mathrm{RBC}$, red blood cell. 
Table 1.

Biomarker studies assessing primary venous thromboembolism risk in cancer patients

\begin{tabular}{|c|c|c|c|c|c|c|c|}
\hline Biomarker & Study Design & Cancer Type & $\begin{array}{l}\text { Number of } \\
\text { patients }\end{array}$ & $\begin{array}{l}\text { Biomarker Cutoff } \\
\text { or Numeric } \\
\text { Variable }\end{array}$ & Statistic & $95 \% \mathrm{CI}$ & Reference \\
\hline \multicolumn{8}{|c|}{ Leukocyte count } \\
\hline & Prospective & Mixed & 2701 & $>11 \times 10^{9} / \mid$ & OR 2.2 & $1.2-4$ & 9 \\
\hline & Prospective & Mixed & 4405 & $>11 \times 10^{9} / 1$ & HR 2.10 & $1.30-3.40$ & 209 \\
\hline & Prospective & Solid tumor & 665 & Per 2-fold increase & HR 1.15 & $0.63-2.11$ & 210 \\
\hline \multicolumn{8}{|l|}{ Platelet count } \\
\hline & Prospective & Mixed & 2701 & $2350 \times 10^{9} / 1$ & OR 1.8 & $1.1-3.2$ & 9 \\
\hline & Prospective & Mixed & 4405 & $2350 \times 10^{9} / 1$ & HR 1.83 & $1.19-2.83$ & 209 \\
\hline & Prospective & Solid tumor & 665 & $\geq 443 \times 10^{9} / 1$ & HR 3.50 & $1.52-8.06$ & 210 \\
\hline & Prospective & Mixed & 1023 & $2350 \times 10^{9} / 1$ & OR 2.53 & $1.35-4.74$ & 14 \\
\hline \multicolumn{8}{|l|}{ D-dimer } \\
\hline & Prospective & Colorectal & 176 & $>0.3 \mu \mathrm{g} / \mathrm{ml}$ & HR 6.53 & $1.58-27.0$ & 211 \\
\hline & Prospective & Gynecologic & 267 & $>5 \mu \mathrm{g} / \mathrm{ml}$ & OR 1.19 & $1.04-1.37$ & 212 \\
\hline & Prospective & Mixed & 124 & $>0.65 \mu \mathrm{g} / \mathrm{ml}$ & HR 4.04 & $1.22-13.3$ & 213 \\
\hline & Prospective & Mixed & 112 & Per 2-fold increase & HR $1.76^{*}$ & $1.32-2.35$ & 214 \\
\hline & Prospective & Mixed & 821 & $\geq 1.44 \mu \mathrm{g} / \mathrm{ml}$ & HR 1.8 & $1.0-3.2$ & 215 \\
\hline & Retrospective & Lung & 108 & $>1.50 \mu \mathrm{g} / \mathrm{ml}$ & HR 11.0 & $2.62-46.2$ & 216 \\
\hline & Prospective & Pancreatic & 140 & $22.16 \mu \mathrm{g} / \mathrm{ml}$ & HR 4.9 & $1.0-23.1$ & 81 \\
\hline & Prospective & Mixed & 946 & $\begin{array}{l}\text { Per } 10 \mu \mathrm{g} / \mathrm{ml} \\
\text { increase }\end{array}$ & sHR 1.31 & $1.00-1.73$ & 112 \\
\hline \multicolumn{8}{|l|}{$\begin{array}{l}\text { Soluble P- } \\
\text { selectin }\end{array}$} \\
\hline & Prospective & Mixed & 112 & Per 2-fold increase & HR $2.44^{*}$ & $1.31-4.53$ & 214 \\
\hline & Prospective & Glioma & 76 & $\mathrm{n} / \mathrm{a}$ & HR 1.068 & $1.017-1.122$ & 132 \\
\hline & Prospective & Mixed & 797 & $\begin{array}{l}\text { Per } 10 \mathrm{ng} / \mathrm{ml} \\
\text { increase }\end{array}$ & HR 1.19 & $1.07-1.33$ & 134 \\
\hline & Prospective & Mixed & 687 & $253.1 \mathrm{ng} / \mathrm{ml}$ & HR 2.6 & $1.4-4.9$ & 221 \\
\hline & Prospective & Mixed & 946 & $\begin{array}{l}\text { Per } 10 \mathrm{ng} / \mathrm{ml} \\
\text { increase }\end{array}$ & sHR 1.05 & $1.00-1.73$ & 112 \\
\hline \multicolumn{8}{|l|}{$\begin{array}{l}\text { Extracellular } \\
\text { vesicles }\end{array}$} \\
\hline & Prospective & Mixed & 728 & $\geq 4.62 \mathrm{nM}$ PS & HR 0.95 & $0.55-1.64$ & 33 \\
\hline \multirow{6}{*}{$\begin{array}{l}\text { Tissue factor- } \\
\text { positive } \\
\text { extracellular } \\
\text { vesicles }\end{array}$} & Prospective & Pancreas & 60 & Per 2-fold increase & HR 1.5 & $1.0-2.4$ & 55 \\
\hline & & Brain & 119 & & HR 0.9 & $0.7-1.3$ & \\
\hline & & Stomach & 43 & & $\mathrm{n} / \mathrm{a}$ & $\mathrm{n} / \mathrm{a}$ & \\
\hline & & Colorectal & 126 & & HR 0.9 & $0.6-1.6$ & \\
\hline & Prospective & Multiple myeloma & 122 & $>11.8 \mathrm{fM} \mathrm{Xa} / \mathrm{min}$ & OR 1.4 & $0.4-4.7$ & 79 \\
\hline & Prospective & Mixed & 648 & $\geq 13 \%$ & sHR 1.0 & $0.99-3.8$ & 80 \\
\hline
\end{tabular}

Transl Res. Author manuscript; available in PMC 2021 November 01. 


\begin{tabular}{|c|c|c|c|c|c|c|c|}
\hline Biomarker & Study Design & Cancer Type & $\begin{array}{l}\text { Number of } \\
\text { patients }\end{array}$ & $\begin{array}{l}\text { Biomarker Cutoff } \\
\text { or Numeric } \\
\text { Variable }\end{array}$ & Statistic & $95 \% \mathrm{CI}$ & Reference \\
\hline & Retrospective & Pancreaticobiliary & 117 & $22.5 \mathrm{pg} / \mathrm{ml}$ & OR 4.78 & $1.64-13.98$ & 56 \\
\hline & Prospective & Pancreatic & 140 & $\geq 2.37 \mathrm{pg} / \mathrm{ml}$ & HR 10.5 & $1.5-72.4$ & 81 \\
\hline & Meta-analysis & Solid tumor & $\mathrm{n} / \mathrm{a}$ & $\mathrm{n} / \mathrm{a}$ & OR 1.76 & $1.21-2.56$ & 82 \\
\hline \multicolumn{8}{|c|}{ Neutrophil extracellular traps } \\
\hline H3Cit & Prospective & Mixed & 946 & $\begin{array}{l}\text { Per } 100 \mathrm{ng} / \mathrm{ml} \\
\text { increase }\end{array}$ & sHR 1.11 & $1.03-1.20$ & 112 \\
\hline Cell free $D N A$ & Prospective & Mixed & 946 & $\begin{array}{l}\text { Per } 100 \mathrm{ng} / \mathrm{ml} \\
\text { increase }\end{array}$ & sHR $1.03^{*}$ & $0.96-1.10$ & 112 \\
\hline Nucleosome & Prospective & Mixed & 946 & Per 1 unit increase & sHR $0.95^{*}$ & $0.89-1.02$ & 112 \\
\hline \multirow{3}{*}{$\begin{array}{l}\text { Neutrophil-to- } \\
\text { lymphocyte ratio }\end{array}$} & Prospective & Solid tumor & 810 & $>3$ & HR 1.37 & $0.52-3.57$ & 113 \\
\hline & Prospective & Solid tumor & 1469 & Per 2-fold increase & sHR 1.2 & $1.0-1.4$ & 114 \\
\hline & Retrospective & Gastric & 112 & $>3$ & HR $0.8^{*}$ & $0.3-2.5$ & 6 \\
\hline \multicolumn{8}{|c|}{ Inflammatory molecules } \\
\hline \multirow[t]{2}{*}{$I L-1 \beta$} & Prospective & Mixed & 726 & Per 2-fold increase & HR $0.98^{*}$ & $0.80-1.20$ & 131 \\
\hline & Prospective & Glioma & 76 & Per 2-fold increase & HR $1.046^{*}$ & $0.732-1.495$ & 132 \\
\hline$I L-3$ & Prospective & Mixed & 726 & Per 2-fold increase & HR $0.99^{*}$ & $0.84-1.18$ & 131 \\
\hline \multirow[t]{2}{*}{$I L-4$} & Prospective & Mixed & 726 & Per 2-fold increase & HR $1.11^{*}$ & $0.86-1.42$ & 131 \\
\hline & Prospective & Glioma & 76 & Per 2-fold increase & HR $0.907^{*}$ & $0.634-1.298$ & 132 \\
\hline \multirow[t]{5}{*}{$I L-6$} & Retrospective & Ovarian & 200 & $5-19.9 \mathrm{pg} / \mathrm{ml}$ & HR 7.98 & $0.99-64.0$ & 129 \\
\hline & & & & $\geq 20 \mathrm{pg} / \mathrm{ml}$ & HR 8.90 & $1.04-76.0$ & \\
\hline & Prospective & $\begin{array}{l}\text { Diffuse large B cell } \\
\text { lymphoma }\end{array}$ & 322 & $>$ Detection limit & sHR 1.07 & $0.56-2.06$ & 130 \\
\hline & Prospective & Mixed & 726 & Per 2-fold increase & HR $1.08^{*}$ & $0.98-1.20$ & 131 \\
\hline & Prospective & Glioma & 76 & Per 2-fold increase & HR $0.894^{*}$ & $0.602-1.328$ & 132 \\
\hline \multirow[t]{2}{*}{$I L-8$} & Prospective & Mixed & 726 & Per 2-fold increase & HR $1.06^{*}$ & $0.94-1.20$ & 131 \\
\hline & Prospective & Glioma & 76 & Per 2-fold increase & HR $0.918^{*}$ & $0.585-0.585$ & 132 \\
\hline \multirow[t]{3}{*}{$I L-10$} & Prospective & $\begin{array}{l}\text { Diffuse large B cell } \\
\text { lymphoma }\end{array}$ & 322 & $\unlhd$ Median value & sHR 1.66 & $0.84-3.26$ & 130 \\
\hline & Prospective & Mixed & 726 & Per 2-fold increase & HR $1.01 *$ & $0.83-1.22$ & 131 \\
\hline & Prospective & Glioma & 76 & Per 2-fold increase & HR $0.822^{*}$ & $0.505-1.340$ & 132 \\
\hline \multirow[t]{2}{*}{$I L-11$} & Prospective & Mixed & 726 & Per 2-fold increase & HR $0.90^{*}$ & $0.76-1.06$ & 131 \\
\hline & Prospective & Glioma & 76 & Per 2-fold increase & HR $0.621^{*}$ & $0.284-1.357$ & 132 \\
\hline \multirow[t]{2}{*}{$C C L 3$} & Prospective & Mixed & 726 & Per 2-fold increase & HR $0.99^{*}$ & $0.90-1.10$ & 131 \\
\hline & Prospective & Glioma & 76 & Per 2-fold increase & HR 0.348 & $0.146-0.830$ & 132 \\
\hline \multirow[t]{3}{*}{$T N F-a$} & Prospective & $\begin{array}{l}\text { Diffuse large B cell } \\
\text { lymphoma }\end{array}$ & 322 & $\searrow 0.285 \mathrm{pg} / \mathrm{ml}$ & $\operatorname{sHR} 0.77^{*}$ & $0.46-1.29$ & 130 \\
\hline & Retrospective & Metastatic colorectal & 45 & $<6.6 \mathrm{pg} / \mathrm{ml}$ & HR 0.17 & $0.04-0.75$ & 133 \\
\hline & Prospective & Glioma & 76 & Per doubling & HR $1.097^{*}$ & $0.697-1.727$ & 132 \\
\hline
\end{tabular}




\begin{tabular}{|c|c|c|c|c|c|c|c|}
\hline Biomarker & Study Design & Cancer Type & $\begin{array}{l}\text { Number of } \\
\text { patients }\end{array}$ & $\begin{array}{l}\text { Biomarker Cutoff } \\
\text { or Numeric } \\
\text { Variable }\end{array}$ & Statistic & $95 \% \mathrm{CI}$ & Reference \\
\hline \multirow[t]{2}{*}{ Soluble VEGF } & Prospective & Mixed & 797 & $\begin{array}{l}\text { Per } 10 \mathrm{pg} / \mathrm{ml} \\
\text { increase }\end{array}$ & HR 1.04 & $1.00-1.09$ & 134 \\
\hline & Prospective & Glioma & 76 & Per 2-fold increase & HR $0.995^{*}$ & $0.640-1.548$ & 132 \\
\hline \multirow{4}{*}{$\begin{array}{l}\text { Podoplanin } \\
\text { (tissue) }\end{array}$} & Prospective & Brain & 213 & $<50 \%$ expression & HR 2.44 & $0.73-8.17$ & 143 \\
\hline & & & & 50-70\% expression & HR 3.28 & $0.91-11.75$ & \\
\hline & & & & $>70 \%$ expression & HR 5.71 & $1.52-21.36$ & \\
\hline & Retrospective & Glioma & 165 & $\geq 30 \%$ expression & OR 3.423 & $\begin{array}{l}1.083- \\
10.814\end{array}$ & 151 \\
\hline \multirow[t]{2}{*}{$\begin{array}{l}\text { Isocitrate } \\
\text { dehydrogenase } 1\end{array}$} & Prospective & Brain & 213 & $\begin{array}{l}\text { IDH1 R132H } \\
\text { mutation }\end{array}$ & HR 0.11 & $0.01-0.83$ & 150 \\
\hline & Retrospective & Glioma & 165 & $\begin{array}{l}\text { IDH1 R132H } \\
\text { mutation }\end{array}$ & OR 0.101 & $0.010-0.975$ & 151 \\
\hline
\end{tabular}

* Denotes a univariable analysis. All other statistics are given for multivariable analyses. CCL3, chemockine ligand 3; CI, confidence interval; HR, hazard ratio; IL, interleukin; OR, odds ratio; PS, phosphatidylserine; sHR, subdistribution hazard ratio; TNF-a, tumor necrosis factor-a; VEGF, vascular endothelial growth factor. 
Table 2.

Biomarker studies assessing recurrent venous thromboembolism risk in cancer patients

\begin{tabular}{|c|c|c|c|c|c|c|c|}
\hline Biomarker & Study Design & Cancer Type & $\begin{array}{l}\text { Number of } \\
\text { patients }\end{array}$ & $\begin{array}{l}\text { Biomarker Cutoff or } \\
\text { Numeric Variable }\end{array}$ & Statistic & 95\% CI & Reference \\
\hline \multicolumn{8}{|l|}{ Tissue factor } \\
\hline & Prospective & Mixed & 805 & $>64.6 \mathrm{pg} / \mathrm{ml}$ & sHR 3.4 & $2.1-5.5$ & 225 \\
\hline \multicolumn{8}{|c|}{ C-reactive protein } \\
\hline & Prospective & Mixed & 482 & $>75 \mathrm{mg} / \mathrm{l}$ & sHR 2.3 & $1.2-4.4$ & 225 \\
\hline & Prospective & Mixed & 99 & $>4.5 \mathrm{mg} / \mathrm{l}$ & sHR 9.82 & $1.86-51.7$ & 227 \\
\hline \multicolumn{8}{|c|}{ Soluble P-selectin } \\
\hline & Prospective & Mixed & 117 & $>136 \mathrm{ng} / \mathrm{ml}$ & sHR 4.4 & $1.3-16$ & 226 \\
\hline \multicolumn{8}{|l|}{ D-dimer } \\
\hline & Prospective & Mixed & 117 & $>4.0 \mu \mathrm{g} / \mathrm{ml}$ & $\operatorname{sHR} 2.5^{*}$ & $0.76-7.9$ & 226 \\
\hline & Prospective & Mixed & 111 & $\begin{array}{l}>600 \mathrm{ng} / \mathrm{ml} \\
>\text { age } \times 10 \mathrm{ng} / \mathrm{ml}\end{array}$ & $\begin{array}{l}\text { sHR } 5.81 \\
\text { sHR } 5.11\end{array}$ & $\begin{array}{l}1.06-31.72 \\
1.032-25.3\end{array}$ & 227 \\
\hline
\end{tabular}

Transl Res. Author manuscript; available in PMC 2021 November 01. 
Table 3.

Biomarker studies assessing primary arterial thromboembolism risk in cancer patients

\begin{tabular}{|c|c|c|c|c|c|c|c|}
\hline Biomarker & Study Design & $\begin{array}{l}\text { Cancer } \\
\text { Type }\end{array}$ & $\begin{array}{l}\text { Number of } \\
\text { patients }\end{array}$ & $\begin{array}{l}\text { Biomarker Cutoff or } \\
\text { Numeric Variable }\end{array}$ & Statistic & $95 \% \mathrm{CI}$ & Reference \\
\hline Neutrophil count & Prospective & Mixed & 1883 & $>4.9 \times 10^{9} / 1$ & sHR 2.4 & $1.3-4.6$ & 228 \\
\hline Soluble P-selectin & Prospective & Mixed & 1883 & $>46.3 \mathrm{ng} / \mathrm{ml}$ & sHR 2.1 & $1.2-3.8$ & 228 \\
\hline D-dimer & Prospective & Mixed & 1883 & Per 2-fold increase & sHR 1.1 & $0.9-1.4$ & 228 \\
\hline $\begin{array}{l}\text { Neutrophil-to- } \\
\text { lymphocyte ratio }\end{array}$ & Prospective & Mixed & 1469 & Per 2-fold increase & sHR 1.2 & $0.9-1.6$ & 114 \\
\hline $\begin{array}{l}\text { Platelet-to-lymphocyte } \\
\text { ratio }\end{array}$ & Prospective & Mixed & 1469 & Per 2-fold increase & sHR 1.1 & $0.7-1.5$ & 114 \\
\hline $\begin{array}{l}\text { Citrullinated histone } \\
\mathrm{H} 3\end{array}$ & Prospective & Mixed & 957 & Per 100 ng/ml increase & $\operatorname{sHR} 1.0^{*}$ & $0.7-1.4$ & 229 \\
\hline Cell free DNA & Prospective & Mixed & 957 & Per $100 \mathrm{ng} / \mathrm{ml}$ increase & $\operatorname{sHR} 1.0^{*}$ & $0.9-1.2$ & 229 \\
\hline Nucleosome & Prospective & Mixed & 957 & Per unit increase & $\operatorname{sHR} 1.1^{*}$ & $1.0-1.2$ & 229 \\
\hline
\end{tabular}


Table 4.

Comparison of biomarker assays and challenges for clinical use

\begin{tabular}{|c|c|c|c|c|}
\hline Biomarker & Assay & Clinical Assay & Comments & Reference \\
\hline \multicolumn{5}{|l|}{ Leukocyte count } \\
\hline & $\mathrm{CBC}$ & Yes & Routinely acquired in clinical practice & \\
\hline \multicolumn{5}{|l|}{ Platelet count } \\
\hline & $\mathrm{CBC}$ & Yes & Routinely acquired in clinical practice & \\
\hline \multirow[t]{4}{*}{ D-dimer } & ELISA & Yes & & \\
\hline & ELFA & Yes & Reference units not standardized & 217 \\
\hline & Latex-based assay & Yes & $(1 \mathrm{FEU} \sim 2 \mathrm{DDU})$ & \\
\hline & Whole blood assay & Yes & & \\
\hline Soluble P-selectin & ELISA & No & & \\
\hline \multirow[t]{4}{*}{ EVs } & Flow cytometry & No & & \\
\hline & Electron microscopy & No & Subject to varied pre-analytical challenges (blood & \\
\hline & Confocal microscopy & No & collection trauma, centrifugation protocol) & $25,34,36$ \\
\hline & Atomic force microscopy & No & See ISEV and ERCC for more details and protocols & \\
\hline \multicolumn{5}{|l|}{$\mathrm{TF}^{+} \mathrm{EV}$} \\
\hline & Flow cytometry & No & Monocytes may be contaminating TF source & $67,71,85,86$ \\
\hline & ELISA & No & $\begin{array}{l}\text { Poor anti-TF antibody specificity Monocytes may be } \\
\text { contaminating TF source }\end{array}$ & \\
\hline & Factor Xa generation & No & $\begin{array}{l}\text { Variable specificity depending on exact methods May be } \\
\text { labor intensive with high interassay variability }\end{array}$ & $67,71,83$ \\
\hline & Fibrin generation & No & Monocytes may be contaminating TF source & $67,71,84$ \\
\hline \multicolumn{5}{|l|}{ H3Cit } \\
\hline & ELISA & No & & 116 \\
\hline \multirow[t]{4}{*}{$\begin{array}{l}\text { Inflammatory } \\
\text { markers }\end{array}$} & $\begin{array}{l}\text { ELISA } \\
\text { ELISPOT }\end{array}$ & $\begin{array}{l}\text { Yes } \\
\text { Yes }\end{array}$ & & \\
\hline & & & Subject to pre-analytical challenges (blood & \\
\hline & PCR & Yes & collection tubes, processing time, freeze-thaw use, & 136 \\
\hline & Multiplexed assay & Yes & storage) & \\
\hline \multicolumn{5}{|l|}{ Podoplanin (tissue) } \\
\hline & Immunohistochemistry & Yes & Requires invasive tissue collection & \\
\hline \multicolumn{5}{|l|}{ IDH1 (tissue) } \\
\hline & Immunohistochemistry & Yes & Requires invasive tissue collection & \\
\hline \multicolumn{5}{|l|}{ miRNAs } \\
\hline & qRT-PCR & Yes & Biased RNA isolation and library kits can change & \\
\hline & Hybridization assay & Yes & results & $36,164-166$ \\
\hline & NGS & Yes & $\begin{array}{l}\text { Lack of endogenous normalization controls See ERCC } \\
\text { for recommended protocols }\end{array}$ & \\
\hline
\end{tabular}

CBC, complete blood count; DDU, D-dimer unit; ELFA, enzyme-linked immunofluorescence assay; ELISA, enzyme-linked immunosorbent assay; ELISPOT, enzyme-linked immune spot assay; EV, extracellular vesicle; FEU, fibrinogen equivalent unit; IDH1, isocitrate dehydrogenase 1;

miRNA, micro RNA; NGS, next-generation sequencing; qRT-PCR, quantitative reverse transcription polymerase chain reaction; $\mathrm{TF}^{+} \mathrm{EV}$, tissue factor-positive extracellular vesicles

Transl Res. Author manuscript; available in PMC 2021 November 01. 